\title{
FROM THE PACIFIC TO THE TROPICAL FORESTS: NETWORKS OF SOCIAL INTERACTION IN THE ATACAMA DESERT, LATE IN THE PLEISTOCENE ${ }^{1}$
}

\author{
DESDE EL PACÍFICO A LA FORESTA TROPICAL: REDES DE INTERACCIÓN \\ SOCIAL EN EL DESIERTO DE ATACAMA DURANTE EL PLEISTOCENO FINAL
}

\author{
Calogero M. Santoro ${ }^{2 *}$,Eugenia M. Gayo ${ }^{3,4}$, José M. Capriles ${ }^{5}$, Marcelo M. Rivadeneira ${ }^{6,7,8}$, Katherine \\ A. Herrera ${ }^{9,2}$, Valentina Mandakovic ${ }^{10}$, Mónica Rallo ${ }^{11}$, Jason A. Rech ${ }^{12}$, Bárbara Cases ${ }^{13}$, Luis Briones ${ }^{14}$, \\ Laura Olguín ${ }^{15}$, Daniela Valenzuela ${ }^{13}$, Luis A. Borrero ${ }^{16}$, Paula C. Ugalde ${ }^{17,2}$, Francisco Rothhammer ${ }^{2}$, \\ Claudio Latorre ${ }^{18,19}$, and Paul Szpak ${ }^{20}$
}

\begin{abstract}
The social groups that initially inhabited the hyper arid core of the Atacama Desert of northern Chile during the late Pleistocene integrated a wide range of local, regional and supra regional goods and ideas for their social reproduction as suggested by the archaeological evidence contained in several open camps in Pampa del Tamarugal (PdT). Local resources for maintaining their every-day life, included stone raw material, wood, plant and animal fibers, game, and fresh water acquired within a radius of $\sim 30$ $\mathrm{km}$ (ca. 1-2 days journey). At a regional scale, some goods were introduced from the Pacific coast (60-80 km to the west, ca. 3-4 days journey), including elongated rounded cobbles used as hammer stones in lithic production, and shells, especially from non-edible species of mollusks. From the Andes (ranging 80-150 km to the east, ca. 5-8 days of journey), they obtained camelid fiber, obsidian and a high-quality chalcedony, in addition to sharing knowledge on projectile point designs (Patapatane and Tuina type forms). Pieces of wood of a tropical forest tree species (Ceiba spp.) from the east Andean lowlands (600 km away, ca. 30 days of journey) were also brought to the PdT. While local goods were procured by the circulation of people within the PdT, the small number of foreign items would have been acquired through some sort of exchange networks that integrated dispersed local communities throughout several ecosystems. These networks may have been a key factor behind the success exhibited by these early huntergatherers in the hyper arid ecosystems of the Atacama Desert at the end of the Pleistocene.

Different lines of archaeological evidence including open camps, workshop-quarries, lithic artifacts, archaeofaunal remains, plant and animal fibers and textiles, archaeobotanical remains, and paleoecological data show that people of the PdT managed a wide range of cultural items from the Pacific coast, the Andean highland and the tropical forest, that were integrated with resources
\end{abstract}

\footnotetext{
${ }^{1}$ An earlier version of this article was presented at the International Workshop "Caravan Archaeologies: En Route to the Past, Present and Future", Pica, Chile (May 2017). This manuscript was evaluated by external reviewers and edited by the editors of the Chungara Editorial Committee.

${ }^{2}$ Instituto de Alta Investigación, Universidad de Tarapacá, Arica, Chile. *Corresponding author: calogero_santoro@yahoo.com; franciscorothhammer@gmail.com

${ }^{3}$ Departamento de Oceanografía, Universidad de Concepción, Concepción, Chile. emgayo@uc.cl

${ }^{4}$ Centro de Ciencia del Clima y la Resiliencia (CR) ${ }^{2}$, Santiago, Chile.

${ }^{5}$ Department of Anthropology, The Pennsylvania State University, Pennsylvania, USA. jmcapriles@gmail.com

${ }^{6}$ Centro de Estudios Avanzados en Zonas Áridas (CEAZA), Coquimbo, Chile. marcelo.rivadeneira@ ceaza.cl

${ }^{7}$ Departamento de Biología Marina, Universidad Católica del Norte, Coquimbo, Chile.

${ }^{8}$ Departamento de Biología, Universidad de La Serena, La Serena, Chile.

${ }^{9}$ Laboratoire de Préhistoire et Technologie, Université Paris Nanterre, Paris, Francia. herreragodoy@ hotmail.com

${ }^{10}$ Camino al Volcán 33411, San José de Maipo, Región Metropolitana, Chile. valentina.mandakovic@yahoo.es

${ }^{11}$ Décima Avenida 1230, depto. 47, San Miguel, Santiago, Chile. monicarallo@yahoo.com.

${ }^{12}$ Department of Geology \& Environmental Earth Science, Miami University, Oxford, Ohio. rechja@miamioh.edu

${ }^{13}$ Departamento de Antropología, Universidad de Tarapacá, Arica, Chile. barbara_cases@yahoo.es; dani.valenzu@gmail.com

${ }^{14}$ Museo Municipalidad de Pica, Pica, Chile. geoglifo2@gmail.com

${ }^{15}$ Programa Doctorado en Antropología UCN-UTA, Universidad Católica del Norte, San Pedro de Atacama, Chile. olguinlaura.o@gmail.com

${ }^{16}$ Consejo Nacional de Investigaciones Científicas y Técnicas, Buenos Aires, Argentina. laborrero@ hotmail.com

${ }^{17}$ School of Anthropology, University of Arizona, Tucson, USA. arqueo.paulaugalde@ gmail.com

${ }^{18}$ Departamento de Ecología \& Centro UC Desierto de Atacama, Pontificia Universidad Católica de Chile, Santiago, Chile. clatorre@ bio.puc.cl

${ }^{19}$ Instituto de Ecología y Biodiversidad (IEB), Santiago, Chile.

${ }^{20}$ Department of Anthropology, Trent University, Peterborough, Ontario, Canada.paulszpak@trentu.ca
}

Recibido: enero, 2018. Aceptado: febrero, 2019.

http://dx.doi.org/10.4067/S0717-73562019005000602. Publicado en línea 3-abril-2019. 
gathered locally within the socio-cultural systems established by the end of the Pleistocene. These results are interpreted as material expressions of multi-scalar networking for resource management and other social material and immaterial requirements, which in other words, means that these people were actively connected to regional (coastal and highland), and supra-regional (trans-Andean) exchange networks from and out of the PdT.

Key words: Local, regional and pan-Andean networks of interaction, Atacama Desert, Pacific coast, Andes, tropical forest.

Los grupos sociales que inicialmente habitaban el núcleo hiperárido del Desierto de Atacama en el norte de Chile durante el Pleistoceno tardío integraron una amplia gama de bienes e ideas, locales, regionales y supra regionales, para su reproducción social, como lo sugieren las evidencias arqueológicas materiales recuperadas en varios campamentos al aire libre en Pampa del Tamarugal (PdT). Los recursos locales para mantener su vida diaria, incluían materias primas líticas, fibras de plantas y animales, presas de caza y agua dulce adquiridos en un radio de $30 \mathrm{~km}$ (ca. 1-2 días de viaje). A escala regional, se introdujeron algunos elementos desde la costa del Pacífico (60-80 km hacia el oeste, ca. 3 a 4 días de viaje), incluidos rodados redondeados alargados, utilizados como percutores en la producción lítica y conchas, especialmente de especies no comestibles de moluscos. Desde los Andes (80-150 km al este, ca. 5-8 días de viaje), obtuvieron fibra de camélido, obsidiana y una calcedonia de alta calidad, además de compartir conocimientos sobre diseños de puntas de proyectil (tipo Patapatane y Tuina). También se llevaron a la PdT trozos de madera de una especie de árbol de los bosques tropicales (Ceiba spp.) de las tierras bajas al este de los Andes (600 km de distancia, ca. 30 días de viaje). Mientras que los bienes locales fueron adquiridos por la circulación de personas dentro de la PdT, el pequeño número de artículos foráneos se adquirieron a través de redes de intercambio que integraron comunidades locales dispersas en varios ecosistemas; lo que debió ser un factor clave detrás del éxito demostrado por estos primeros cazadores-recolectores en los ecosistemas hiperáridos del Desierto de Atacama hacia el final del Pleistoceno.

Diferentes líneas de evidencia arqueológica que incluyen campamentos al aire libre, talleres, canteras, artefactos líticos, restos arqueofaunales, fibras y textiles de plantas y animales, restos arqueobotánicos y datos paleoecológicos, muestran que la gente de la PdT manejaron una amplia gama de elementos culturales desde la costa del Pacífico, el altiplano andino y el bosque tropical, que se integraron a los recursos recolectados localmente dentro de los sistemas socioculturales establecidos al final del Pleistoceno. Estos resultados se interpretan como una expresión material de una red de múltiples escalas para la gestión de recursos y otros requisitos sociales e inmateriales, lo que en otras palabras, significaría que estos grupos sociales estaban conectados activamente con redes de interacción regionales (costa y tierras altas) y supra-regionales (transandinas) desde y hacia la PdT.

Palabras claves: redes de interacción locales, regionales y pan-andinas, Desierto de Atacama, Costa del Pacífico, Andes, bosque tropical.

For scattered populations of hunter-gatherers, the need and the ability to maintain networks of social interaction is crucial to assure access to both utilitarian and non-utilitarian goods and to gather survival information, especially during times of shortage (Dillehay 2013; Veth 2008; Whallon 2006). Here we attempt to show that the hunter-gatherer societies that initially inhabited the Pampa del Tamarugal (PdT) basin, an intermediate depression between the Pacific coast and the Andes (Figure 1) in the hyper arid core of the Atacama Desert, needed to develop and maintain extensive mechanisms for the transference of non-utilitarian and utilitarian goods (found in the archaeological record) as well as partners and information, which in turn allowed them to create social networks, essential for the sustainability of their sociocultural systems within hyper arid environments by the end of the Pleistocene. Hence, people that initially settled within the Atacama Desert, albeit likely at low population densities, should have developed strong and dynamic social networks at local, regional and supraregional scales.

Unlike highly institutionalized later Andean circulation (e.g., Dillehay 2013; Dillehay and Núñez
1988; Núñez and Nielsen 2011; Salomon 1985), the transference of items and movement of people among late Pleistocene hunter-gatherer societies could have been operated under less structured systems. Particularly, the transport of low-frequency items may have occurred by means of several mechanisms of both direct and indirect acquisition. Direct mechanisms may include: the incidental acquisition of goods fixed in circuit of residential and logistic mobility (Binford 1979), for instance through transhumance (Dillehay 2013; Lynch 1971); as well as non-utilitarian mobility by long- and short-distance special-purpose trips (Gould and Saggers 1985; Grove 2014; Lovis et al. 2005; Newlander 2012; Pearce 2014; Speth et al. 2013; Whallon 2006). Indirect mechanisms may included: direct and indirect (down-the-line) economic exchange of utilitarian and non-utilitarian items (Dillehay 2013; Laguens et al. 2007; McBryde 1984; Mulvaney 2002; Silveira et al. 2010; Tripcevich 2010; Veth 2008; Wiessner 2002; Wilkins et al. 2010); flux of resources as part of marriages (bride price/ service) (Walker et al. 2011); and incidental deposition of allochthonous goods as a result of visits and other sporadic and non-systematic activities (e.g., Gusinde 


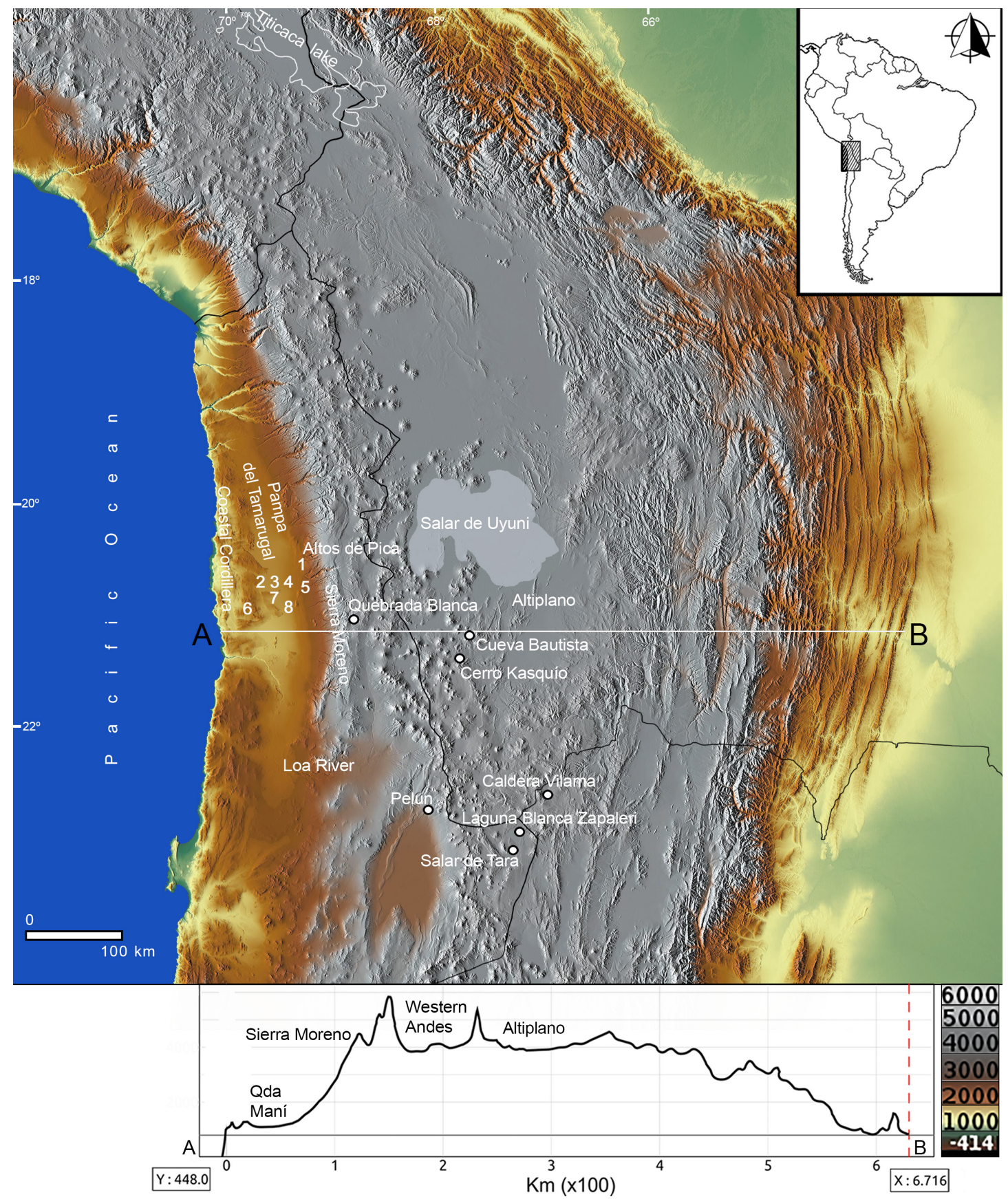

Figure 1. Late Pleistocene open camps distribution in Pampa del Tamarugal basin, in the core of the Atacama Desert (after Herrera 2017): (1) Quebrada Chipana (Chipana-1); Quebrada Guatacondo: (2) Pampa Ramaditas-4 (PR4), (3) Pampa Ramaditas-5 (PR5), (4) Pampa Ramaditas-7 (PR7); Quebrada Maní: (5) Quebrada Maní 12 (QM12), (6) Salar de Llamara 17 (SL117); (7) Quebrada Maní 35 (QM35), and (8) Quebrada Maní 32 (QM32).

Distribución de campamentos abiertos del Pleistoceno Tardío en la cuenca Pampa del Tamarugal, en el núcleo del Desierto de Atacama (tomado de Herrera 2017): (1) Quebrada Chipana (Chipana-1); Quebrada Guatacondo: (2) Pampa Ramaditas-4 (PR4), (3) Pampa Ramaditas-5 (PR5), (4) Pampa Ramaditas-7 (PR7); Quebrada Maní: (5) Quebrada Maní 12 (QM12), (6) Salar de Llamara 17 (SLl17); (7) Quebrada Maní 35 (QM35) y (8) Quebrada Maní 32 (QM32). 
1991 [1974]:130-134; Méndez et al. 2017; Pallo and Borrero 2015).

All of these mechanisms imply social interaction and the setting of social networks, which in turn allowed the procurement of exotic goods of prestige and sacred importance, but also expanding kinship and socio-politic relationships and getting ecological, geographical, and social information for "insurance purposes" (Grove 2014:3573), all of which have evolutionary advantages for social and biological reproduction (Cummings 2014; Dalton 1977; Gamble 1982; Gamble 1999; Gould and Saggers 1985; Hamilton et al. 2007; Newlander 2012; Pearce 2014; Politis 1996; Speth et al. 2013; Whallon 2006). The initial bands of huntergatherers (possibly ca. 25 people), such as those who initially explored the open landscapes of the PdT, required to constantly move and eventually join other groups to avoid extinction (Kelly 1995; Tolan-Smith 2003). Several small interconnected groups moving separately over a large territory increase the likelihood that they can learn more about a region and later share this knowledge, which would clearly improve their survival and adaptation capacities (Kelly 1995, 2003; Pearce 2014). Societies subject to extreme insecurities of key resources such as water, like those that inhabited the hyper arid ecosystems of the Atacama Desert, were more dependent on long-distance social networks (Gould and Saggers 1985:122).

The problem is the difficulty to identify and distinguish archaeologically direct and indirect mechanisms of acquisition / transfer of goods (Close 2000; Costin 2001). Although the presence of exotic goods in hunter-gatherer contexts is often explained by mobility, there is an increasing archaeological, ethnographic and ethnohistorical recognition that hunter-gatherers practiced various forms of exchange (Bate 1986; Cummings 2014; Dalton 1977; Delage 2018; Dillehay 2013; Gusinde 1991; Jordan 2014; McBryde 1984; Standen et al. 2018; Veth 2008). Our objective is not to discriminate the type of specific mechanism of acquisition / transference of goods that operated among late Pleistocene PdT hunter-gatherers because the availability of material is limited. Rather, based on ongoing interdisciplinary studies that integrated the available archaeological, isotopis and paleoecological data, we attempt to show the different geographical scales in which the networks of interactions functioned within these societies. We propose three kinds of network for resource management and other social material and immaterial requirements: local, regional and supra-regional scales. We aim to reconstruct and discuss how people integrated vastly different territories and eventually built dynamic socio-cultural interaction networks in the Atacama Desert during the late Pleistocene.

\section{The Pampa del Tamarugal}

The Atacama Desert expands across the western flank of the Andes, extending from southern Peru to the Copiapó valley $\left(\sim 17^{\circ}-27^{\circ} \mathrm{S}\right)$. Across these $>1,400$ $\mathrm{km}$, the relief rises from the Pacific coast to the highelevation Altiplano, and is accompanied by an abrupt elevation-precipitation gradient with widespread hyper aridity across the coast and low-elevation areas (02,000 masl), arid climates prevail along the pre-Andean cordillera $(2,000-4,000$ masl), with semi-arid but cold conditions over the Altiplano (>3,500 masl).

The PdT is a multi-aquifer system of more than $4,000 \mathrm{~km}^{2}$ that lies within the central valley in the hyper arid core of the Atacama Desert. Here, the extreme negative hydrological balance leads to a landscape that is practically devoid of biotic and water resources. Nevertheless, the localized discharge of surficial and groundwater resources generates discrete oases for life. In fact, within deeply incised valleys (or quebradas) that drain the precordillera are dense riparian ecosystems that occur alongside perennial/ephemeral streams (Gajardo 1994; Luebert and Pliscoff 2006; Villagrán et al. 1999). Typically, these ecosystems in the northern Atacama $\left(17^{\circ}-21^{\circ} \mathrm{S}\right)$ incorporate endemic and native herbaceous and woody taxa such as Escallonia angustifolia, Baccharis spp., Morella pavonis (syn. Myrica pavonis), and Schinus molle, among others. Except for a few rodents, lizards, birds and amphibious species, the native faunal assemblage in these formations is limited (Marquet et al. 1998). Within the central valley, the localized evaporation and outcropping from shallow groundwater table maintains salt pans (salares) along the western margin of the PDT with phreato-halophytic vegetation consisting of Prosopis trees (P. tamarugo and P. alba), shrubs (Tessaria absinthioides) and herbaceous taxa (i.e., Distichlis spicata, Atriplex atacamensis) (Briner 1985; Luebert and Pliscoff 2006).

Paleoecological reconstructions for the ecological and hydrological setting of our study area show that during the Pleistocene-Holocene transition (13,000 9,000 cal yr BP) the hyper arid core of the Atacama Desert was a hospitable environment for humans. During this period, the PdT contained key resources (fresh water, plants, and game, plus good quality lithic raw materials) for the settling of small groups of huntergatherers that centered their life within this ecosystem. The PdT may have served also as an ecological corridor 
connecting five different ecosystems on the western Andean slope: (a) the Pacific coast and Cordillera de la Costa 60-80 km to the west of the PdT, (b) the quebradas that drain the Andes $60-70 \mathrm{~km}$ to the east, (c) the Altiplano in the high Andes $80-150 \mathrm{~km}$ to the east, (d) the exoreic valleys to the north, and (e) the Loa River and the Salar de Atacama basin towards the south. Ecosystems between the Pacific coast and the tropical forests were more continuous than today, facilitating a long distance network of interaction and making transcontinental movement less difficult, both of which were crucial during this epoch of very low population density (Gayo et al. 2015).

Indeed, late Pleistocene human occupations of the PdT coincided in large part with a boom in local ecosystem productivity that arose from wetter conditions over the Andes (Gayo et al. 2012; Nester et al. 2007; Pfeiffer et al. 2018). These conditions occurred during the second stage of the Central Andean Pluvial Event (CAPE II; 13,000 - 9,800 cal yr BP, (Gayo et al. 2012), in which amplified precipitation in the high Andes induced significant positive hydrological budgets within the hyper arid core of the Atacama between $18^{\circ}$ and $25^{\circ} \mathrm{S}$ (Gayo et al. 2012; Nester et al. 2007; Sáez et al. 2016). As a result, excess runoff from the highlands produced fertile green oases with abundant biotic resources along the low-elevation desert (Gayo et al. 2012; Nester et al. 2007). The associated archaeological sites we have studied were synchronous with CAPE II, although paleoclimate data suggest equivalent paleoecological and hydroclimatic conditions during the first CAPE stage (17,500-14,200 cal yr BP) yet no archaeology date to this period has been identified. Anomalous earlier and later dates of marine shell, wood, and plant remains are not considered within this time frame because of the marine reservoir effect and the presence of old - subfossil- wood (Table 1; Herrera 2017; Joly et al. 2017; Latorre et al. 2013).

\section{Networks of Interaction}

The archaeological evidence summarized below is presented to discuss multi-scalar networking practiced by hunter-gatherers occupying the PdT during the end of the Pleistocene, which we tentatively define as local (within the PdT), regional (coastal and highland), and supra-regional (trans-Andean) networks of interaction. Archaeological data come from one quarry (Cerro Chipana) linked to a workshop open camp in Quebrada Chipana (Chipana-1), and several open camps, all of which have been excavated and well-dated at the distal section of the alluvial fans of Quebrada Guatacondo: Pampa Ramaditas-4 (PR4), Pampa Ramaditas-5 (PR5), Pampa Ramaditas-7 (PR7), and Quebrada Maní: Quebrada Maní 12 (QM12), Quebrada Maní32 (QM32), Quebrada Maní 35 (QM35), and Salar de Llamara 17 (SL117). Forty-eight AMS dates have been obtained from these sites, excluding the last two sites (not yet dated), and these fluctuate between 12,420 to 9370 cal yr BP. These sites show that these people were well-adapted to the Atacama Desert as they contain abundant stone tools of different local and extra-local raw material and technology, processed plant and animal fibers, modified sea shells, and faunal remains associated, in some cases, with hearths and other features.

\section{Local network}

The local network corresponds to a social space that has been archaeologically identified within the southern section of the PdT circumscribed between the mouth and proximal section of the fan of the quebradas that drain into the eastern margin of this basin, and their distal section. Within a radius of 15 to $20 \mathrm{~km}$ we have inventoried five large archaeological areas: (1) the proximal section of the alluvial fan of Quebrada Maní (QM), (2) the distal section of the alluvial fan of the same quebrada and the canyon to the north - Pintados, (3) the distal alluvial fan section section of Quebrada Guatacondo known as Pampa Ramaditas (PR), (4) the quarry and work shop of Quebrada and Cerro Chipana (Chi) and (5) Salar de Llamara (SLl), all of them covered with open camps numbered as QM12, QM32, QM35 PR4, PR5, PR7, Chi-1, and SL117, (Figure 1). The camps were part of a complex socioeconomic mobility system that took advantage of local resources generated by the and contemporaneous paleowetland and riparian ecosystems where the sites used to be located, which were available in the PdT during CAPE II (Boyd and Richerson 2005; Santoro et al. 2017).

The hunter-gatherers who inhabited these sites manifested technical knowledge and a concomitant socio-economic and technological organization, which included a wide range of lithic reduction techniques encompassing both simple and highly complex attributes, and the management of locally available resources, listed below:

\section{(a) Lithic raw material}

Silicified fine-grained cherts, fine-grained sedimentary dark rocks (lutites), and quartzitic sandstone 
C. M. Santoro, E. M. Gayo, J. M. Capriles, M. M. Rivadeneira, K. A. Herrera, V. Mandakovic, M. Rallo, J. A. Rech, B. Cases, L. Briones, L. Olguín, D. Valenzuela, L. A. Borrero, P. C. Ugalde, F. Rothhammer, C. Latorre, and P. Szpak

Table 1. Compilation of 48 AMS dates from five archeological site areas defined at Pampa del Tamarugal (PdT). Recopilación de 48 fechas AMS obtenidas en cinco áreas con sitios arqueológicos en la Pampa del Tamarugal (PdT).

\begin{tabular}{|c|c|c|c|c|c|c|c|}
\hline Site & Unit & Sumple ID & Material & ${ }^{14} \mathrm{C}$ age & SD & Age cal yr BP* & Reference \\
\hline Chipana 1 & Test pit 3, E1B & UCIAMS 126285 & Plant material & 8390 & 25 & 9370 & Herrera 2017 \\
\hline Chipana 1 & Test pit 5. surfice & UCIAMS 146016 & Marine shell & 8835 & 30 & 9045 & Herrera 2017 \\
\hline Chipana 1 & Test pit 5 , surfice & UCIAMS 146015 & Marine shell & 8860 & 35 & 9090 & This study \\
\hline Quebrada Maní 32 & S88W45 level 3 & UCIAMS134394 & Plant material & 9290 & 510 & 10500 & This study \\
\hline Chipana 1 & Test pit 5, E2 & UCIAMS 145144 & Charcoal & 9965 & 30 & 11310 & Herrera 2017 \\
\hline Chipana 1 & Test pit 5, E3 & UCIAMS 145142 & Charcoal & 9970 & 35 & 11320 & Herrera 2017 \\
\hline Chipana 1 & Test pit 5, E1 & UCIAMS 145139 & Charcoal & 9975 & 30 & 11320 & Herrera 2017 \\
\hline Chipana 1 & Test pit 5, E4 & UCIAMS 145146 & Charcoal & 9995 & 30 & 11355 & Herrera 2017 \\
\hline Chipana 1 & Test pit 5, E1 & UCIAMS 145140 & Charcoal & 10005 & 30 & 11370 & Herrera 2017 \\
\hline Quebrada Maní 32 & S1E8 lñevel 1B & UCIAMS 134397 & Plant material & 10005 & 45 & 11390 & This study \\
\hline Chipana 1 & Test pit 5, E3 & UCIAMS 145143 & Charcoal & 10010 & 30 & 11380 & Herrera 2017 \\
\hline Pampa Ramadita 7 & Test pit $1 / 1 \mathrm{~A}-\mathrm{R} 2$ & UCIAMS 165644 & Plant material & 10010 & 80 & 11450 & This study \\
\hline Chipana 1 & Test pit 5, E1 & UCIAMS 145141 & Charcoal & 10020 & 30 & 11410 & Herrera 2017 \\
\hline Quebrada Maní 32 & S1E8 2B/feature 2 & UCIAMS 134418 & $\begin{array}{c}\text { Plant material, } \\
\text { cordage (acid only) }\end{array}$ & 10040 & 35 & 11470 & This study \\
\hline Chipana 1 & Test pit 5, E4 & UCIAMS 145145 & Charcoal & 10045 & 30 & 11470 & Herrera 2017 \\
\hline Chipana 1 & Test pit 5, E1 & UCIAMS 145138 & Charcoal & 10080 & 35 & 11535 & Herrera 2017 \\
\hline Quebrada Maní 12 & Stratum 2 & UCIAMS 89015 & Plant material & 10080 & 25 & 11530 & Latorre et al. 2013 \\
\hline Quebrada Maní 32 & S1E8 level 1 & UCIAMS 134396 & Plant material & 10085 & 35 & 11540 & This study \\
\hline Pampa Ramadita 7 & Test pit 1/1A-R1 & UCIAMS 165643 & Plant material & 10105 & 30 & 11600 & This study \\
\hline Quebrada Maní 32 & S1E8 2B/feature 2 & UCIAMS134417 & $\begin{array}{l}\text { Rodent pellet (acid } \\
\text { only) }\end{array}$ & 10115 & 35 & 11620 & This study \\
\hline Quebrada Maní 12 & Stratum 3 & UCIAMS 89020 & Plant material & 10120 & 25 & 11640 & Latorre et al. 2013 \\
\hline Quebrada Maní 12 & Stratum 4 & UGAMS 8241 & Wood & 10130 & 30 & 11660 & Latorre et al. 2013 \\
\hline Quebrada Maní 12 & Stratum 4 & UCIAMS 89017 & Plant material & 10160 & 25 & 11740 & Latorre et al. 2013 \\
\hline Quebrada Maní 12 & Stratum 4 & UCIAMS 89021 & Plant material & 10165 & 25 & 11750 & Latorre et al. 2013 \\
\hline Quebrada Maní 32 & S1E8 level 2B/feature 2 & UCIAMS 134399 & Plant material & 10180 & 40 & 11780 & This study \\
\hline Quebrada Maní 32 & S1E8 level 1 & UCIAMS 134406 & Charcoal & 10195 & 35 & 11820 & This study \\
\hline Quebrada Maní 32 & S1E8 level 1 & UCIAMS 134402 & Charcoal & 10205 & 35 & 11840 & This study \\
\hline Quebrada Maní 12 & Stratum 5 & UGAMS 7050 & Charcoal & 10210 & 30 & 11850 & Latorre et al. 2013 \\
\hline Quebrada Maní 32 & S1E8 level 2B & UCIAMS134398 & Plant material & 10210 & 35 & 11850 & This study \\
\hline Quebrada Maní 32 & S1E8 level 2B & UCIAMS 134405 & Charcoal & 10210 & 45 & 11840 & This study \\
\hline Quebrada Maní 32 & S1E8 level 1B & UCIAMS134404 & Charcoal & 10215 & 45 & 11850 & This study \\
\hline Quebrada Maní 12 & Stratum 4 base & UGAMS 8242 & Wood & 10220 & 30 & 11870 & This study \\
\hline Quebrada Maní 32 & S1E8 level 1 & UCIAMS 134403 & Charcoal & 10220 & 40 & 11860 & This study \\
\hline Quebrada Maní 12 & Stratum 4 base & UGAMS 8243 & Wood & 10340 & 30 & 12040 & Latorre et al. 2013 \\
\hline Quebrada Maní 12 & Stratum 3 & UCIAMS 89022 & Animal coprolite & 10360 & 30 & 12100 & Latorre et al. 2013 \\
\hline Quebrada Maní 12 & Stratum 5 & UCIAMS 84347 & Charcoal & 10365 & 25 & 12100 & Latorre et al. 2013 \\
\hline Pampa Ramadita 5 & Test pit 1/1A-R1 & UCIAMS 165640 & Plant material & 10370 & 30 & 12140 & This study \\
\hline Pampa Ramadita 5 & Test pit 1/1B-R3 & UCIAMS 165642 & Plant material & 10425 & 30 & 12230 & This study \\
\hline Quebrada Maní 32 & S88W45, level 4 & UCIAMS134395 & Plant material & 10445 & 45 & 12240 & This study \\
\hline Quebrada Maní 12 & Stratum 2 & UCIAMS 89019 & Plant material & 10505 & 25 & 12420 & Latorre et al. 2013 \\
\hline Quebrada Maní 12 & Stratum 2 & UCIAMS 89458 & Marine shell & 10655 & 25 & 11410 & Latorre et al. 2013 \\
\hline Quebrada Maní 12 & Stratum 2 & UGAMS 7049 & Charcoal & 10800 & 30 & 12700 & Latorre et al. 2013 \\
\hline Quebrada Maní 12 & Stratum 4, feature 13 & UCIAMS 89018 & Charcoal & 10930 & 30 & 12750 & Latorre et al. 2013 \\
\hline Quebrada Maní 32 & S88W45, level 4 & UCIAMS 134400 & Charcoal & 12540 & 60 & 14710 & This study \\
\hline Quebrada Maní 32 & S88W45, level 3 & UCIAMS 134401 & Charcoal & 12580 & 50 & 14830 & This study \\
\hline Chipana 1 & Test pit 3, E2B & UCIAMS & Carbonated plant & 12750 & 35 & 15140 & Herrera 2017 \\
\hline Chipana 1 & Test pit 5, E7 & UCIAMS 145147 & Plant materia & 14030 & 680 & 16880 & Herrera 2017 \\
\hline Pampa Ramadita 5 & Test pit $1 / 1 \mathrm{~A}-\mathrm{R} 1$ & UCIAMS 165641 & Charcoal & 14160 & 45 & 17180 & This study \\
\hline
\end{tabular}

* Terrestrial samples were calibrated using the SHCAL13 curve. Marine samples using Marine13 curve assuming a local $r$ effect of $367^{14} \mathrm{C}$ yrs BP $( \pm 198)$ according to Latorre et al. (2016) 
sourced from the Altos de Pica Formation (in the northeast section of the PdT) are of good knapping quality and are commonly found on the surface at camp localities and dispersed over the landscape (Latorre et al. 2013).

Another common lithic raw material is a white opaline silica (Blanco and Tomlinson 2013) that was quarried and collected from Cerro Chipana, a huge quarry site next to Chipana-1 (Figure 2). At this particular workshop raw material was transformed into advanced stages of large biface artifacts (Herrera 2017), which were then exported to neighboring sites like PR5, PR7, QM12, QM32, QM35 and reworked; creating a circulation of material between 20 and $30 \mathrm{~km}$ from the Cerro Chipana quarry.

\section{(b) Animal resources}

Bone archaeological remains show that large artiodactyls, including guanaco (Lama guanicoe) and possibly vicuña (Vicugna vicugna), along with medium-sized rodents such as tuco tuco (Ctenomys sp.) and chinchilla rats (Abrocoma sp.), as well as a few birds were consumed. It is possible that these animals were locally available and hence locally hunted, as they could be attracted to the paleowetlands, making the camps strategic locations for foraging wild resources. Some of the camelid remains consist of neonates, suggesting that hunters might have been present during the early wet season (DecemberJanuary) when these animals are born. This does not rule out the entry of fauna from the highlands, as is suggested by isotope analyses on animal fiberdiscussed below - that indicate highlands origin for some of the bone remains. Moreover, the fragmented nature of the faunal assemblages suggests intensive consumption of the animals as well as the weathering of the bones by salts as these were exposed to hyper arid conditions.

\section{(c) Plant fiber yarn}

Yarn and other remains of processed plant fibers were found at excavated stratigraphic levels from QM32. A few elements $(n=8)$ of cotton and another unidentified plant fiber, locally cut and gathered were employed to prepare knots, twisted fiber and $\mathrm{Z}$ spun yarn, made through further processing or disintegration of the fiber. One sample of cotton (monochrome strand $\mathrm{Z}$ ) was isotopically analyzed and had a $\delta 13 \mathrm{C}$ value of $-24.1 \%$. Relative to cotton fibers from the Azapa valley dated to the Formative Period (average $\delta^{13} \mathrm{C}$ $=-23.2 \%$ o) this lower value for the single PdT fiber may be indicative of the wetter conditions in this region as discussed previously. The $\delta^{13} \mathrm{C}$ values of $\mathrm{C} 3$ plants (such as cotton) are sensitive to water availability, with low water availability producing relatively high (less negative) $\delta 13 \mathrm{C}$ values in plant tissues (Farquhar and Richards 1984; Stewart et al. 1995).

\section{(d) Plant resources}

Freshwater was widely available across these ravines. Consequently, riparian vegetation supported either by surface runoff or groundwater discharge was available. These ecosystems included tree (E. angustifolia, $S$. molle, M. pavonis, P. tamarugo, Bacharis scandens) and shrub (e.g. Caesalpinia aphylla, Atriplex spp.) species that provided fuel for the camps (Gayo et al. 2012; Joly et al. 2017; Nester et al. 2007). Likewise, several herbaceous plants were also present as archaeological refuse consumed in the open camps, including Typha, Cyperaceae, Chenopodium, Cisthante sp., Cortaderia atacamenis, Poaceae, and D. spicata (Gayo et al. 2012), which have a variety of uses such as fodder, food, medicinal, tinctorial, construction and as raw materials for cordages (Villagrán et al. 1999; Villagrán et al. 2003).

\section{(e) Pigments}

Pigments were also circulated within the PdT, although their origins are still unknown. No chemical analyses have been carried out to identify their origin and compare them with the chemical composition of the early pigments mined from the interior of the coast of Taltal south of the PdT (Salazar et al. 2011), and contemporaneous with their camps.

\section{Regional networks}

Based on material introduced from the coast and the high Andes, found in small quantities in most of the open camps and the workshop-quarry, we estimate that people from the PdT organized or were a part of regional social network of interaction with access directly or indirectly to the Pacific coast and the Andes (Figure 1). We also estimate that the acquisition of foreign items was embedded or was part of more complex social interactions, not materialized in archaeological material, which are discussed below.

\section{Coastal network}

This coastal regional network of interaction integrated the Pacific coast located $60-80 \mathrm{~km}$ to the 


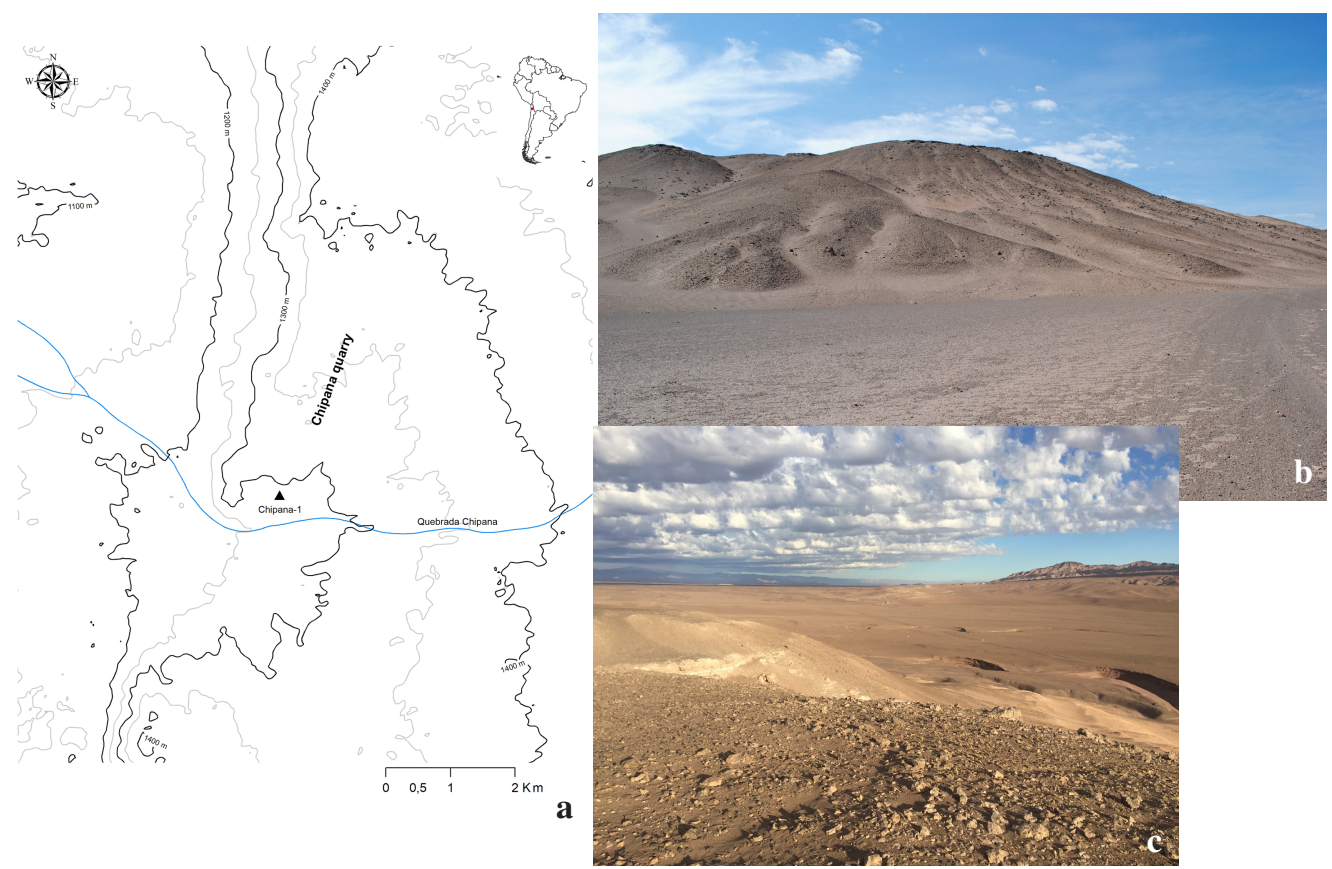

Figure 2. Chipana lithic quarry/workshop: (a) plan view of Chipana canyon, quarry hill and Chipana-1 workshop (drawn by Alonso Maldonado after Herrera 2017); (b) South flank of Cerro Chipana with the outcrop of siliceous rocks (c) top of the outcrop hill looking toward Chipana canyon to the south east and the silver mine Cerro Challacollo (images by Calogero Santoro).

Taller cantera lítica de Chipana: (a) Ubicación planimétrica de la Quebrada Chipana, cantera y campamento taller Chipana-1 (dibujado por Alonso Maldonado tomado de Herrera 2017); (b) flanco sur de Cerro Chipana con afloramiento de rocas silíceas; (c) vista desde la cima de la cantera hacia la Quebrada Chipana en el sur este y Cerro Challacollo con mina de plata hacia el sur oeste (imágenes de Calogero Santoro).

west. From this network hunter-gatherers obtained a selection of shells from marine benthic mollusks and cobbles, that were modified.

(a) Shells

The following small shells have been found in the PdT: Nassarius gayi (cf. Priene scabrum), cf. Leukoma thaca, Crepipatella dilatata, and litorinids (Figure 3). Fissurella crassa and Concholepas concholepas of larger size have also been identified. These ecofacts and artifacts were found in the stratigraphy and the surface of QM12, QM32, and QM35. In Chipana-1 we found only C. concholepas. Additionally, the small species Felicioliva peruviana, $c$. P. scabrum littorinids was found on the surface of all of these sites except Chipana. At PR4, PR5, and PR7 sites, no marine shells have been identified. With the exception of $C$. concholepas and $L$. thaca these species are for the most part infrequently found in Holocene archaeological shell middens of the hyper arid coast of northern Chile (Bird 1943). Yet, they are common in modern natural assemblages (Guzmán et al. 1998; Laudien et al. 2007), as well as in the Pleistocene fossil record of Peru and northern Chile (Ortlieb et al. 1995; Paskoff et al. 1995; Rivadeneira and Carmona 2008).

N. gayi (Figure 3a) is a non-edible small snail (up to $14 \mathrm{~mm}$ in length) that inhabits sandy and muddy sediments from 0-15 $\mathrm{m}$ depth with a modern distribution from Isla Lobos de Afuera in Peru $\left(6^{\circ} \mathrm{S}\right)$, to Cape of Horn in southern Chile ( $55^{\circ} \mathrm{S}$ ) (Guzmán et al. 1998; Marincovich 1973; Reid and Osorio 2000). Its presence in coastal shell middens of northern Chile has been described for Taltal between 8,000-5,600 cal yr BP (Olguín 2013). This is the most represented mollusk at the QM12 site $(\mathrm{n}=30)$. All complete specimens have a distinctive human-made hole in the body of the shell, and were probably used as ornaments. One of these was directly dated to 12,200 cal yr BP (a 400 years reservoir correction was applied to the dated sample) (Latorre et al. 2013), and was coeval with the rest of the dated materials of the site.

F. peruviana (=Oliva peruviana, Figure $3 \mathrm{~b})$ is a nonedible taxon that inhabits subtidal water in soft bottoms, between 4-10 $\mathrm{m}$ depth, with a modern distribution from Sechura Bay, Peru $\left(5^{\circ} \mathrm{S}\right)$ to Lota in southern Chile $\left(37^{\circ} \mathrm{S}\right)$. These taxa reach up to $55 \mathrm{~mm}$ in length (Guzmán et al. 
1998; Osorio 2002). The oldest record of $F$. peruviana in coastal shell middens is $9400-8100 \mathrm{cal}$ yr BP in Huentelauquén, central Chile (Vásquez et al. 1998). Because this species does not have alimentary properties, it was probably used for ornamental purposes.

L. thaca (= Prothaca thaca, Figure 3c) is an edible taxon that inhabits soft bottoms, from the intertidal to $15 \mathrm{~m}$ depth, reaching sizes up to $108 \mathrm{~mm}$ length (Huber 2010). This species is distributed from Chicama, Peru $\left(7^{\circ} \mathrm{S}\right)$ to the Chonos Archipelago in southern Chile $\left(43^{\circ} \mathrm{S}\right)$ (Alamo and Valdivieso 1997). This taxon is currently exploited by the artisanal fleet and consumed by humans along the coast of Chile (Jerez and Figueroa 2008). The oldest record of this species in shell middens of Chile is ca. 9,000 cal yr BP, in Los Vilos in central Chile (Báez et al. 2003), but its presence in shell middens of northern Chile starts at ca. $7100 \mathrm{cal} \mathrm{yr} \mathrm{BP}$ (I-9817) in Camarones (Niemeyer and Schiappacasse 1979).

C. concholepas or loco, the Chilean abalone, is an edible taxon native to the Pacific coast of Chile and Peru with a modern distribution between $5^{\circ} \mathrm{S}$ to $55^{\circ} \mathrm{S}$. The species inhabits the low intertidal zone to $50 \mathrm{~m}$ depth (Häussermann and Försterra 2009) and reaches sizes up to $179 \mathrm{~mm}$ in length (Vermeij 2012). The oldest record of loco in the shell middens of Chile is between 12,57012,140 cal yr BP at the Los Rieles site in central Chile (Jackson et al. 2012).

\section{(b) Cobbles}

Rounded, and often highly elongated cobbles (Figure 4), were most likely selected by humans from Pacific coastal environments and transported to the PdT by direct or indirect mechanisms to be used as hammer instruments due to their hardness. These cobbles are highly polished, likely due to abrasion by waves on the coast. Such well-rounded and hard cobbles are uncommon in the PdT as large and prolonged stream discharge events, critical for rounding and polishing stones, are infrequent. The PdT is too proximal to the adjacent Andes for such cobbles to form. Indeed, the majority of well-rounded cobbles found profusely in the PdT streams are typically comprised of soft ignimbrite lithologies, which are unusable as hammer stones.

\section{Highland network}

Andean regional networks of interactions resulted in human transportation of raw materials (obsidian, chalcedony, and camelid fiber) to the PdT sites. Moreover, highland projectile point types have been identified, indicating that the acquisition of physical material may have been linked to the transferring of certain technological knowledge, among other social businesses. a

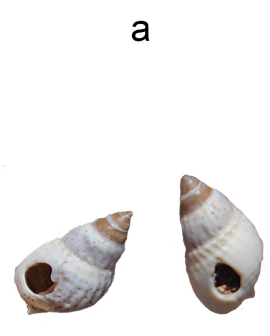

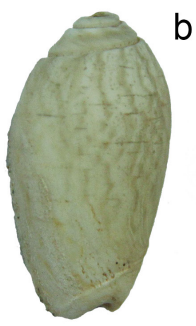

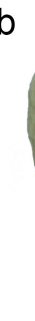

C

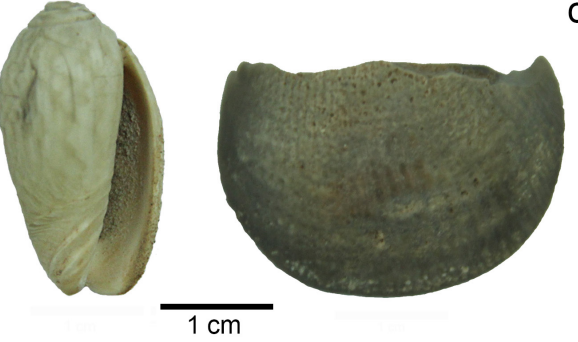

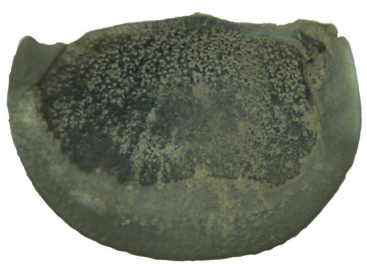

Figure 3. The coastal circuit of interaction showed by shells of the marine benthic mollusks from the Pacific littoral $60-80 \mathrm{~km}$ to the west from Pampa del Tamarugal: (a) Nassarius gayi from QM12, (b) Felicioliva peruviana from QM35, and (c) cf. Leukoma thaca from QM35.

El circuito costero de interacción evidenciado por conchas de moluscos bentónicos del litoral Pacífico, 60-80 km al oeste de la Pampa del Tamarugal: (a) Nassarius gayi de QM12, (b) Felicioliva peruviana, de QM35, y (c) cf. Leukoma thaca de QM35. 

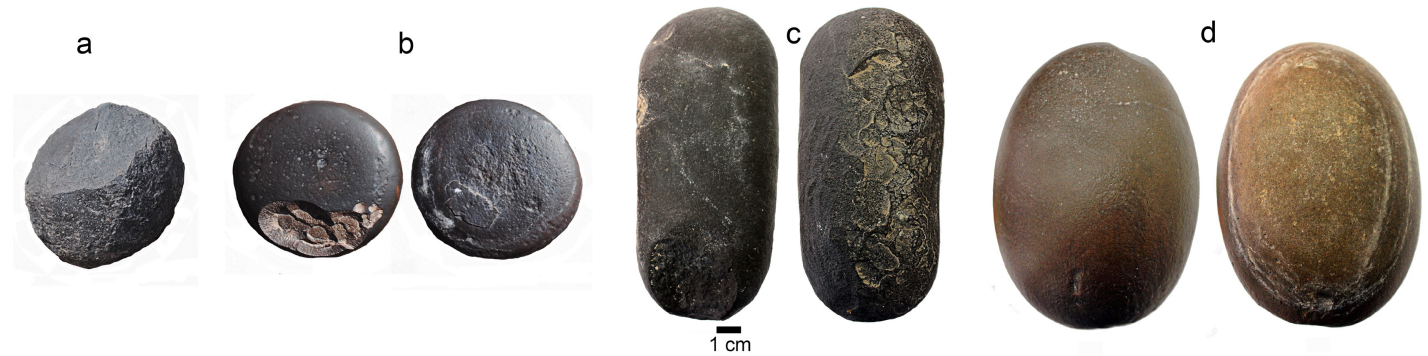

Figure 4. Coastal rounded cobbles used as hammer stones and found in different archaeological sites in Pampa del Tamarugal: (a) Chipana, (b-d) Quebrada Maní 35 (images by Wilfredo Faudes [a and b] and Paola Salgado [c and d]).

Cantos rodados de la costa usados como percutores, encontrados en distintos sitios arqueológicos en la Pampa del Tamarugal: (a) Chipana, (b) y (c) Quebrada Maní 35, (d) Quebrada Maní 12 (imágenes de Wilfredo Faudes [a y b] Paola Salgado [c y d]).

\section{(a) Obsidian}

Obsidian is a high-quality volcanic raw material typically found in the highlands. At least five different obsidian sources have been characterized in the neighboring southern Altiplano, including Pelun, Salar de Tara, Cerro Kaskio, Laguna Blanca/Zapaleri and Caldera Vilama (Capriles et al. 2018; Seelenfreund et al. 2010; Yacobaccio et al. 2004). The closest known obsidian source to Quebrada Maní is Cerro Kaskio, situated approximately $150 \mathrm{~km}$ to the east. Cueva Bautista, a high-elevation temporary camp -located at the same latitude of our study area- was occupied around the same time as the late Pleistocene occupations of the PdT. It is located $15 \mathrm{~km}$ away from Cerro Kaskio, and contains abundant evidence of Cerro Kaskio obsidian (Capriles et al. 2016).

Energy-dispersed $\mathrm{x}$-ray fluorescence and instrumental neutron activation analyses suggest that the QM12 obsidian flake and a distal fragment of a triangular blade projectile point from SL117 correspond to two different but still unidentified obsidian sources. Furthermore, a retouched obsidian flake from a somewhat later (early Holocene) human occupation in Quebrada Blanca, an open camp located between the PdT and Cueva Bautista (Osorio, Capriles, et al. 2017), was sourced to Salar de Tara (Figure 1).

The date of obsidian flake from QM12, as it was recovered from the A horizon beneath a desert pavement, would fluctuate between ca. 12,200 and 11,900 cal yr BP, corresponding to the temporal period defined for the site. At SL117 (a site located in Salar de Llamara, a late Pleistocene fresh water basin, hydrographically linked to Quebrada Mani, and currently a dry salt pan) the blade of a large obsidian projectile point, of still unknown chronology, was recovered from the surface, embedded in the saltpan next to other lithic debitage of different raw materials (Figure 5a). As these former lagoon ecosystems collapsed at ca. 10,000 to 9000 cal yr BP (Pfeiffer et al. 2018), it is likely that this obsidian point was brought before that time, roughly contemporaneous or slightly later than the occupation of QM12. Transportation of small quantities of obsidian from the high Andes was not rare at open camps in Pacific coastal region of southern Peru (Rademaker et al. 2013), contemporaneous with QM12, which are thought to be part of exchange networks that included the circulation of processed fish (Reitz et al. 2016).

Similarly, south of the PdT, late Pleistocene hunter-gatherers living on pre-Andean ecological zones (2000-3800 masl) also obtained obsidian from highland environments linked to paleolake habitats that were gradually colonized based on a seasonal network of interaction (Grosjean et al. 2005; Loyola et al. 2017; Núñez et al. 2002; Núñez et al. 2018).

\section{(b) Chalcedony}

Chalcedony is another raw material with no local sources, which is consistent with its rare occurrence in PdT archaeological sites. We found on the surface of PR5 the base of a projectile point manufactured on a fine-grained brownish lustrous chalcedony (Figure 5b). A few other flakes of this same exogenous raw material have been found in QM32, QM34 and QM35. The second most abundant raw material in the late Pleistocene occupation of Cueva Bautista in the highlands of Bolivia, following Cerro Kaskio obsidian, is a fine-grained jasper-like lustrous chalcedony that ranges in color from beige to burgundy. This chalcedony is macroscopically very similar to the raw material found in the PdT, but as chalcedony can be macroscopically similar and come from different sources, further analyses are required to confirm that beyond its rarity, it was a highland raw material. 


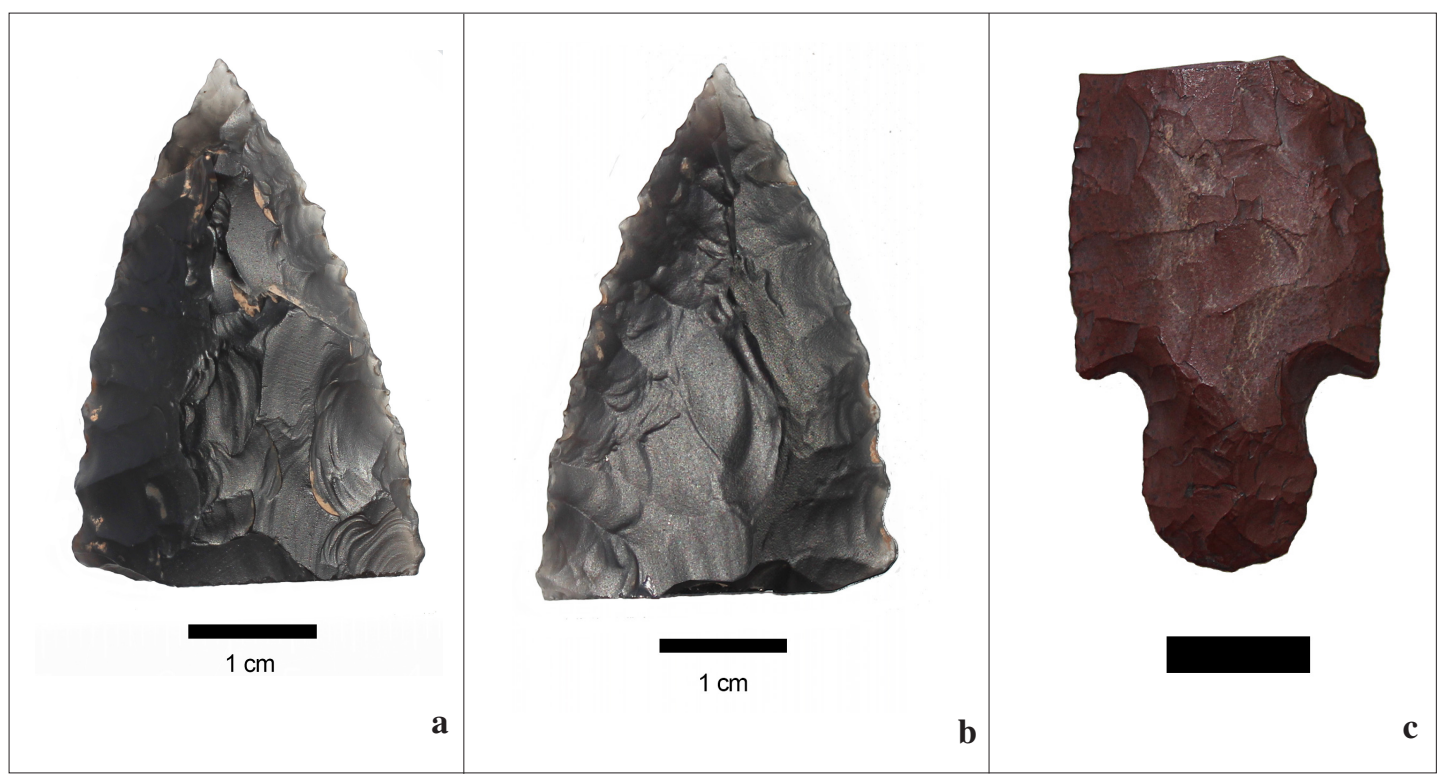

Figure 5. The Andean circuit revealed by highland lithic raw materials: (a) distal tip of an obsidian projectile point registered at Salar de Llamara 17; (b) base of a projectile point manufactured on a fine-grained marron lustrous chalcedony found in Pampa Ramadita 5 site in Pampa del Tamarugal.

Circuito andino evidenciado por materias primas líticas de tierras altas: (a) extremo distal de una punta de proyectil de obsidiana registrada en Salar de Llamara 17; (b) base de una punta de proyectil elaborada sobre cuarzo lustroso de grano fino, encontrado en el sitio Pampa Ramadita 5, Pampa del Tamarugal.

\section{(c) Projectile point types}

Another proxy for the Andean networks of interaction is represented by projectile point types (Patapatane and Tuina) found both in stratigraphy and the surface from open camps in the PdT: QM12, Chipana-1, and QM35. These projectile point types are common in Early Archaic sites in the highlands of northern Chile. The Patapatane type is common in Andean archaeological sites from southern Peru and northern Chile (e.g., Asana, Caru, Patapatane, Hakenasa, and Las Cuevas). The Tuina type form is common in archaeological sites from the Central Atacama (e.g., Tuina, Tambillo, Punta Negra, and Alero El Pescador sites). It has been also recognized in northwestern Argentina (Herrera 2017; Herrera et al. 2015; Latorre et al. 2013; Núñez et al. 2016; Osorio, Steele, et al. 2017; Santoro and Núñez 1987).

\section{(e) Yarn of animal fiber}

Yarn and other remains of processed animal fibers were found at excavated stratigraphic levels from QM32. The major technical innovation was the processing of animal fleece and the production of primary textile structures, such as yarn, felted fleece, and other evidence of animal fiber processing $(n=126)$. Raw materials may have included fibers from guanaco, vicuña, and rodents, along with human hair. Technical action involved cut-shearing, as shown in fiber with few modifications related to procurement or extraction possibly from animal hides; felted fleece, felt stitching, fleece spinning, and hand spinning and twisting or plying, as shown by single yarns, 2 ply yarns and knotted threads. Specifically, a sample of 2-ply yarn found in situ in QM32 was dated to 11,270 cal yr BP (Table 1).

Carbon isotopic analyses of these fibers (fleece and yarn) show a very high contribution of C3 plants, consistent with a highland origin. Considering the prevailing wetter conditions in the high Andes at this time (Gayo et al. 2012), we would expect the Altiplano to be characterized by very few $\mathrm{C} 4$ plants (Still et al. 2003). We analyzed 12 samples of animal fiber, 10 possibly camelids (vicuña and guanaco) and 2 rodents (chinchilla or vizcacha). The fiber samples analyzed include 3 yarn, 5 fleece, 2 twisted fleece, 1 felted fleece, 1 stitched fleece with remains of red pigment. Comparatively, camelid bone collagen from Tiwanaku in the Lake Titicaca basin produced comparable $\delta 13 \mathrm{C}$ 
and $\delta 15 \mathrm{~N}$ values relative to these animal fibers from PdT (Szpak 2013). Adjusting for hair-collagen differences in isotopic discrimination (Szpak et al. 2014) the $\delta 13 \mathrm{C}$ values range between -21.0 and $-18.2 \%$ and the $\delta 15 \mathrm{~N}$ values range between +6.2 and $+8.7 \%$ (Figure 6 , and Supplementary Material 1).

\section{Trans-Andean network}

Data for a trans-Andean connection comes from a piece of wood (ecofacts) found in layer 3 of QM32 (the larger one measuring $8 \mathrm{~cm}$ long and weighing 21.6 gr.). The poor-preservation prevented the determination of whether this pieces formed part of any artifact. There is no direct dates for this wood fragments, but several radiocarbon samples from stratigraphic layer 3 of QM32 site were dated to the late Pleistocene (Table 1).

Anatomical analysis on the larger wood fragment identified it as exotic silk floss tree (cf. Ceiba spp. very similar to Ceiba speciose; Figure 7). Although, a tangential section was observed due to the poor condition of the tissue, it was possible to identify the following anatomical characteristics: simple vessel perforations plates, alternate inter-vessel pits, polygonal shape of alternate pits, fibers of very thin walled, large rays commonly $>10$ seriated, ray height $>1 \mathrm{~mm}$, rays with procumbent, square and upright cells mixed throughout the ray, sheet cells (IAWA-Committee 1989; Richter and Dallwitz 2000 onwards; Tortorelli 1956). These anatomical features are unequivocally attributable to Ceiba spp.

Ceiba spp. (silk floss tree or palo borracho) is a native Malvaceae (subfamily Bombaicodeae) species from the Atlantic seasonal semi-deciduous forest and tropical savannas from eastern South America, where mean annual rainfall ranges between 1,500 and 1,000 $\mathrm{mm} / \mathrm{yr}$, and the mean annual temperature exceeds $18^{\circ} \mathrm{C}$ (Cruz Ruggierom et al. 2002; Killeen et al. 1998). Although paleoclimate data suggest a two-to-four-fold increase in rainfalls during the CAPE II event (Gayo et al. 2012; Latorre et al. 2006; Pfeiffer et al. 2018), the magnitude for such change was not enough to support local populations of Ceiba spp. either at the PdT or over the western Andean slope (Figure 7). But more importantly, paleoclimate transformations in the PdT were related to reduced temperatures and positive hydroclimate anomalies brought about amplified surface and groundwater discharge instead of increased local precipitation (Gayo et al. 2012; Pfeiffer et al. 2018). The fact that hyper arid conditions (i.e. no local rainfalls) remained stable during the CAPE II at PdT, then the record of Ceiba spp. woodfragments in the archaeological context of QM32 necessarily implies intended anthropogenic transport.

\section{Discussion}

Traveling, networking for moving objects, people, and ideas have been key social interactive behaviors in human history (Clarkson et al. 2017; Dillehay 2013; Dillian and White 2010; Hirth and Pillsbury 2013). In Sout America, it seems that since the early colonization of the continent people were linked to a broad network that directly and indirectly connected human groups from a wide range of dispersed ecosystems. This strategy allowed them to get access to a variety of exotic utilitarian (subsistence) and non-utilitarian resources, which in turn helped them to cope with environmental instabilities and food shortages; to reinforce social linkages, political alliances, and kinship extension (including mate exchange); and to avoid conflicts; all of which contributed to social reproduction. The value of transporting non-utilitarian and utilitarian goods is not intrinsic to the good itself. After all, this analytical dichotomy between "necessity and sumptuary" resources is culturally mediated. As the flow of utilitarian and non-utilitarian resources and objects are embedded in social and cultural practices, the decisions of movement do not only concern subsistence (Gould and Saggers 1985; Lovis et al. 2005; Newlander 2012; Politis 1996; Whallon 2006). Local and exotic goods found in the late Pleistocene archaeological record of the PdT were used for a variety of social purposes and functions, including food, tools, personal adornment, and other objects of unknown function.

Almost all the mollusks found are small and many have small holes, which suggests that they were not a primary food source, but selected for other purposes, such as ornamental and ritual with the exceptions of $C$. concholepas, Fissurella spp., and L. thaca. The small size of $N$. gayi likely precluded its use as a food source. It was, however, an ideal primary material for body adornment (Correa 2016). F. peruviana was used as a funerary offering in the Late Archaic Tiliviche cemetery (Standen and Núñez 1984), and became very common since the Formative period ca. 3600 cal yr BP onwards in funerary contexts of northern Chile. These items were brought from the Pacific coast 60-80 km away, and its special purpose is also suggested by its low frequency. Other item brought from the coast, but with utilitarian purpose were the hard-rounded cobbles. They were 


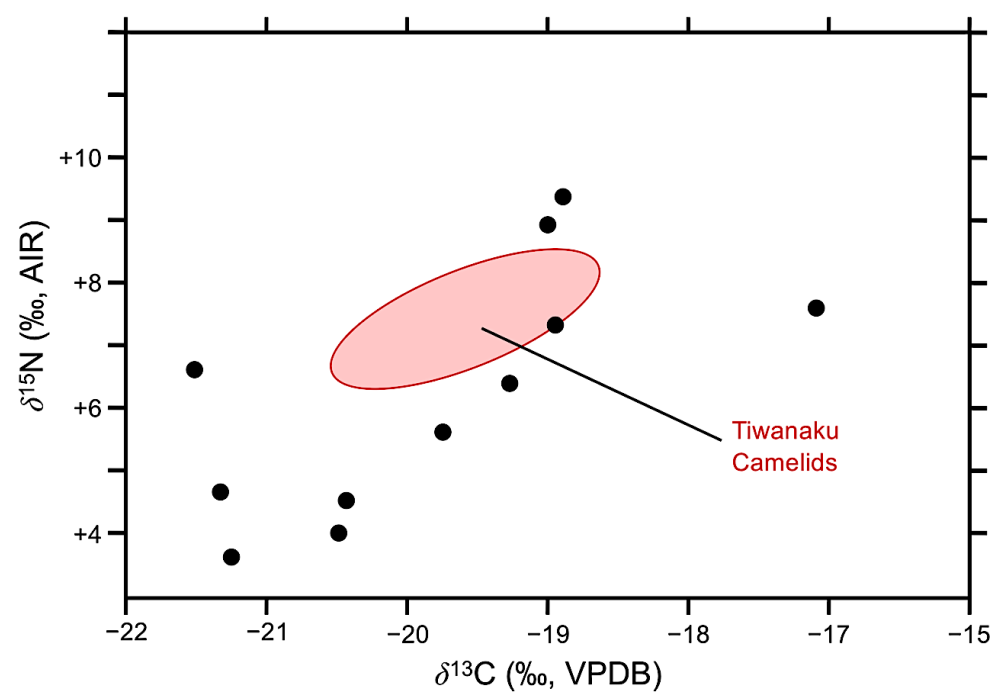

Figure 6. Carbon and nitrogen isotopic compositions of animal fiber samples from Pampa del Tamarugal. For comparative purposes, the standard bivariate ellipse for camelid bone collagen from Tiwanaku is shown to represent camelids consuming a high proportion of $\mathrm{C} 3$ plants. The $\delta^{13} \mathrm{C}$ values of the Tiwanaku camelid bone collagen have been adjusted by $-1.3 \%$ o to account for the difference in diet-tissue discrimination between hair and bone collagen as described in the text.

Composición isotópica de carbono y nitrógeno de muestras de fibras animales de Pampa del Tamarugal. Con fines comparativos, se muestra la elipse bivariada estándar de colágeno de huesos de camélido de Tiwanaku, que consumían una alta proporción de plantas C3. Los valores de $\delta^{13} \mathrm{C}$ del colágeno óseo de Tiwanaku se han ajustado en -1,3\% para dar cuenta de la diferencia en la discriminación entre el tejido y la dieta entre el cabello y el colágeno óseo como se describe en el texto.
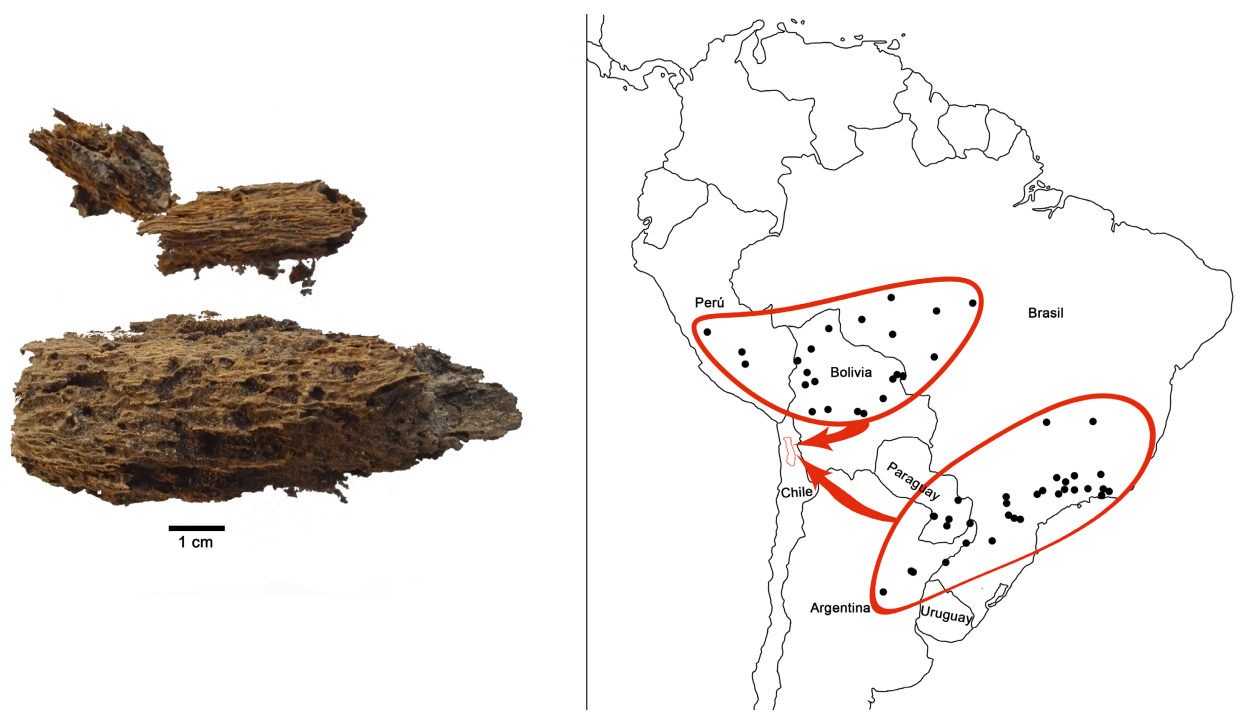

Figure 7. (a) Archaeological wood sample identified as Ceiba spp. (Gibs and Semir 2003); (b) Distribution of Ceiba speciosa in the Amazonian tropical and subtropical zones, away from Pampa del Tamarugal.

(a) Muestra de madera arqueológica identificada como Ceiba spp. (Gibs y Semir 2003); (b) Distribución de Ceiba speciosa en las zonas tropicales y subtropicales amazónicas, alejadas de la Pampa del Tamarugal. 
used as percussion tools in preparing stone artifacts. Suitable stones for hammering are not geologically available in the PdT.

Items from the highlands included obsidian, chalcedony, and camelid fiber, also found in small quantities. As good lithic raw material is locally available, the introduction of foreign stones was not conditioned by the absence of this kind of supply. Animal fibers were also locally available but, according to isotope analyses, some fiber for the production of primary textile structures came from the highlands. Given that different stages of the operational sequence for yarn production were identified, we deduce that the raw material was imported and then locally processed. This interpretation is reinforced by the presence of textile structures made out of local plant fiber (cotton and other unknown taxon), which indicates that these people had the technological knowledge to produce threads, the primary structure for fabrics.

The piece of wood of a tree species (Ceiba spp.) that today occurs in the tropical and subtropical forests to the east of the Andes, ca. $600 \mathrm{~km}$ away, is an item that does not fill the absence of wood raw material. By the end of the Pleistocene the PdT had a good coverage of trees with appropriate wood for tool making. Besides, Ceiba spp. provides a soft and light wood which function in this context is unknown.

The particular set of exotic items found in the PdT, although in small quantities, imply that people were involved in broad social networks that may have included exchange, logistic movements, marriages, and sporadic visits, among others. For the acquisition of these materials, they needed to establish links with other populations, and therefore, with other cultural worlds, languages, landscapes, and ideologies.

Like some contemporaneous hunter-gatherers (Politis 1996), the late Pleistocene hunter-gatherers in the PdT needed to manage different scales of territory, that ranged from a local social territory well known by a band, to very distant lands, known and visited by possibly few members of the group. Within this vast territory, people obtained their supplies from different resources to be incorporated into their socio-cultural subsystems. The mechanisms to access and obtain goods, nevertheless, remain a dilemma. As it has been noticed by several investigators the detection of exotic or imported goods is not enough to distinguish between direct access by mobility and indirect access by exchange (e.g., Costin 2001, Close 2000, Hodder 1982; Pallo and Borrero 2015). As far as we know, however, archaeological indicators evaluated to distinguish both mechanisms are not conclusive. For example, the ratio between the distance to the source of origin and the curve of frequency of the imported objects, from short distances versus objects of long-distance sources do not necessarily represent the extremes of mobility and exchange patterns, respectively. Australian ethnographic and archaeological cases, among others, provide abundant data that show that long-distance movements covering several hundred $\mathrm{km}$ were practiced to obtain socially valuable objects (and therefore not plentiful), along with short and longdistance exchanges for other important items (Gould and Saggers 1985; McBryde 1984; Mulvaney 2002; Veth 2008). Next, we hypothesize the possible ways these mechanisms occurred.

For the local network, the current archaeological data from the PdT allow us to suggest that people managed three basic levels of territorial information as suggested by Rockman (2003:4): locational, limitational and social knowledge. At the locational level, people certainly recognize the places and physical characteristics of local resources for subsistence (i.e., lithic outcrops, wood, game, plant, wetlands). At the limitational level people were familiar with the range of distribution and reliability of local resources, the costs of acquisition, and its usefulness. At the third level, the PdT people created a social knowledge, as they settled and moved throughout the landscape revisiting more regularly camps located in the proximal section of the fluvial fan of the quebradas that drain into the PdT. Their familiarity with this territory increased substantially, conceptually defining the components they recognized, those that were utilized and those that were not, creating a complex human landscape. Due to the predicted low population density in the PdT by the end of the Pleistocene, we estimate that the procurement, translation and integration of local resources by hunter-gatherer societies could have occurred through both logistical and residential mobility.

Regional networks of interaction required different sorts of knowledge and movements. Information would likely have been gathered from social networks linked to other social groups, settled along the Pacific coast or the high Andes. The introduction of low quantities of high-quality Andean lithic raw materials may have occurred through mobility of the PdT groups to those external ecosystems. Alternatively, people may have accessed to the exotic items through large-scale network of exchange or down-the-line trade. For obsidian found in late Pleistocene open camps of the southern Peruvian Pacific coast, which originated more than 130 $\mathrm{km}$ toward the Andes, it has been suggested that it was obtained through the exchange of processed fish within 
a regional network (Rademaker et al. 2013; Reitz et al. 2016). Exchange or down-the-line trade in intermediate territories is a feature assigned to well-established Holocene hunter-gatherers in South America (Dillehay 1999). Considering that the long distance transported items had no food value, and some of them were nonutilitarian and were low frequency items, it may indicate that the purpose for making the effort of accessing coastal and Andean goods was probably motived by social gatherings (e.g., marriages and information exchange). This means that in these and other social gatherings, exotic items could be exchanged to reinforce social bonds that were crucial for the sustainability of late Pleistocene hunter-gatherers living in the shifting and challenging ecosystems of the PdT. The finding of exotic material itself, however, should not be considered as conclusive evidence to distinguish between exchange and direct access. Nonetheless, it should be considered, however, that less than $100 \mathrm{~km}$ separate the PdT and the Pacific coast to the west, and the Andes to the east, thus it may be possible that human groups directly reached the resources of these ecosystem through logistic mobility circuit (Figure 1). This interpretation would need research with a larger geographic scope.

Late Pleistocene hunter gatherers of the PdT managed to obtain resources located beyond the Andes into the tropical lowlands, as is indicated by the taxonomic identification of tropical wood (Ceiba spp.). In other words, it seems likely, that people were part of larger, complex long-distance networks that enabled the circulation of such materials. More importantly, though, was the possibility of the existence of extended networks of interaction for sharing knowledge and for establishing social bonds beyond the band level. Very recent genetic research that examined South American population structure and pre-Hispanic population displacements, utilizing mitochondrial DNA haplogroups of 4200 subjects of extant mixed populations of Mexico, Costa Rica, Venezuela, Colombia, Ecuador, Peru, Bolivia, Brazil, Argentina and Chile, showed that the territories of southern Peru, northern Chile and highland Bolivia were colonized by genetic flows from the Amazon basin (Rothhammer et al. 2017), which in turn reinforces the (Lathrap 1970) hypothesis that the upper Amazon was peopled by upstream population movements using the Amazon river network as a waterway.

\section{Conclusions}

The archaeological evidence presented here shows that various exotic, utilitarian, non-utilitarian and edible goods were introduced and consumed in the PdT (lithic raw materials, wood, animal and plant fibers for tool elaboration, and mollusks for food and other purposes). They were carried from the Pacific coast, the Andean highland and the tropical forest, and were integrated to the resources gathered locally within the PdT. The specific mechanisms for the circulation of these items are uncertain. The distribution of material may have occurred through long-term incursions of people from the PdT, and the encounter with individuals from other ecosystems inside or outside the PdT. These encounters could have happened within rather informal networks of interaction, as suggested by the scarcity of the exotic objects. Connections with the tropical forest, more than $600 \mathrm{~km}$ away, were the consequence of even larger networks of interaction that involved several groups moving within and between ecosystems. Although most of the identified resources could be classified within the "utilitarian" world, there are elements that do not hold nutritional value or cannot be used as raw materials for manufacturing tools. Thus, they were carried because of other social purposes and functions. Besides the circulation of exotic items, the encounter with other peoples should have served to share knowledge and experience on plants and animal behavior, geography, information in managing raw materials and technological practices, as well as marriage arrangements, collaborative social actions. Moreover, the down-the-line transportation of goods should have propitiated also the migration of women and men that interacted along the way from the tropical forest to the Pacific and vice versa.

One of the marks of the functioning of a long-range system of interaction is that beyond the economically necessary transported goods, the distribution of alternative items is also served. Their significance, however, is not obvious, as they may be related to spiritual or ritual necessities or may be the basis for different classes of alliances. The maintenance of local, regional, and supra-regional networks of interaction should have required different kinds of mobility practices involved in the social life of the groups who initially colonized the Atacama Desert. It should be mentioned that rainfall in the highlands during the late Pleistocene was two or three times more abundant than today. These climatic conditions reduced the stark discontinuities of the ecological zones involved in the networks of interaction utilized by hunter-gatherers between the Pacific coast and the tropical forests. Fresh water and natural routes such as rivers and available plants and animals would have made travel more feasible. As connectivity 
was better during the late Pleistocene, it is likely that the continuous landscapes with different resources facilitated a pan-Andean connection beyond the Altiplano. In other words, the late Pleistocene-early Holocene inhabitants of the PdT had the possibility to be part of a broad exchange network that allowed them access to a diversified list of rather conspicuous items brought from both the eastern and western slopes of the Andes.

In sum, the circuit of movement implied in the circulation of the exotic items is still uncertain, but it can be imagined that people at least managed a local circuit of mobility within the PdT of $\sim 200 \mathrm{~km}$ in length (north to south) and $\sim 100 \mathrm{~km}$ in width (east to west). Connections with the external world such as the coast (ca. 60-80 km to the west) and the highland (ca. 80-150 $\mathrm{km}$ to the east) may have involved direct incursions to these ecosystems or the encounter with other groups of people in intermediate territories. Connections with the tropical forest, more than $600 \mathrm{~km}$ away, were possibly the consequence of down-the-line exchange networks that involved several groups in the circulation. Explanations for the introduction of exotic "non-utilitarian" objects, with non-dietary value, into the PdT would be that: (a) as exotic goods they had intangible meanings and were used within socio-cultural performances (i.e., birth and death of group member; marriage; investiture of a new leader; healings); (b) by forming part of these and other behavioral patterns, the action of introduction of these material objects allowed them to create bonds with outside groups to cope with social strategies for the survival and reproduction of the groups; (c) exchange included also sharing meanings imbedded in these objects and transferring information about the outside world.

Acknowledgements: This research was founded by FONDECYT grants 1160744 (to CMS, EG, CL), and 1150031 (FR, JC, CMS), CONICYT/PIA Program project's ANILLO SOC1405 (CMS, EG, JC, DV, CL), PCI PII20150081 (CMS, CL, JC, JR), FONDAP 15110009 to CR2 (EG), and MEC 80160111 (LAB). We thank Wilfredo Faundes and Gabriela Marcelo Jarpa for their help in the archaeological lab, Magda Orell for helping in the wood identification analysis, Paola Salgado, Matias Frugone and Alonso Maldonado for fixing the figures, and the comments of César Méndez and three other external anonymous reviewers of Chungara. Archaeological excavations in the studied sites were authorized by the Consejo de Monumentos Nacionales: Ord. №4379/12, №03352/13, No001478/15, №2203/17, and $\mathrm{N}^{\circ} 4379 / 12$.

\section{References Cited}

Alamo, V. and V. Valdivieso 1997. Lista Sistemática de Moluscos Marinos del Perú. Instituto del Mar del Peru, Callao.

Báez, P., D. Jackson, and M. Bahamondes 2003. Pesquerías prehispánicas de Chile: abundancia de recursos y recolección costera de subsistencia a comienzos del Holoceno en la Provincia de Choapa. In Actividad Pesquera y de Acuicultura en Chile, edited by E. Yánez, pp. 317-325. Pontificia Universidad Católica de Valparaíso, Valparaíso.

Bate, L.F. 1986. El modo de producción cazador recolector o la economía del salvajismo. Boletín de Antropología Americana 13:5-31.

Binford, L.R. 1979. Organization and formation processes: looking at curated technologies. Journal of Anthropological Research 35:255-272.

Bird, J.B. 1943. Excavations in Northern Chile. Anthropological Papers volume XXXVIII, Part IV. The American Museum of Natural History, New York.

Boyd, R. and P.J. Richerson 2005. The Origin and Evolution of Cultures. Oxford Univeristy Press, Oxford.

Blanco, N. and A.J. Tomlinson 2013. Carta Guatacondo, Región de Tarapacá. Carta Geológica de Chile, Serie Geológica Básica, $N^{\circ}$ 156. Servicio Nacional de Geología y Minería - Chile, Subdirección Nacional de Geología, Santiago.

Briner, C. 1985. Caracterización fenotípica de los biotipos de tamarugo en la Pampa del Tamarugal. In Estado Actual del Conocimiento sobre Prosopis tamarugo, edited by M.A. Habit, pp. 233-237. FAO, Santiago.
Capriles, J.M., J. Albarracin-Jordan, U. Lombardo, Daniela Osorio, K.A. Herrera, B. Maley, S.T. Goldstein, A.I. Domic, M.D. Glascock, H. Veit, and C.M. Santoro 2016. High-altitude adaptation and late Pleistocene foraging in the Bolivian Andes. Journal of Archaeological Science, Report 6:463-474.

Capriles, J., N. Tripcevich, A. Nielsen, M. Glascock, J. AlbarracinJordan, and C.M. Santoro 2018. Late Pleistocene lithic procurement and geochemical characterization of the Cerro Kaskio obsidian source in southwestern Bolivia. Archaeometry 59:815-833.

Clarkson, P.B., C.M. Santoro, T.E. Levy, L. Núñez, A. Nielsen, S. Rosen, F. Förster, J.M. Capriles, A.M. Khazanov, M.D. Frachetti, D. Valenzuela, V.G. Standen, B. Cases, G. Pimentel, P. Lecoq, X. Medinacelli, L. Briones, A. Wink, N. Tripcevich, H. Riemer, E. O'Ryan, X. Loayza, T.F. Lynch, and H. Woldekiros 2017. A worldwide network for comparative studies on caravans: past, present and future/ Red mundial para estudios comparativos sobre caravanas: pasado, presente y future. Chungara Revista de Antropología Chilena 49(3):297-307.

Close, A.E. 2000. Reconstructing movement in prehistory. Journal of Archaeological Method and Theory 7:44-77.

Correa, D.E. 2016. Aprovechamiento de los recursos malacológicos asociados a un contexto de almacenamiento en Chan Chan, Perú. Anales de Antropología 50:112-133.

Costin, C.L. 2001. Craft production systems. In Archaeology at the Millennium. A Sourcebook, edited by G.M. Feinman and T.D. Price, pp. 273-350. Springer, New York. 
Cruz Ruggierom, P.G., M.A. Batalha, V.R. Pivello, and S.T. Meirelles 2002. Soil-vegetation relationships in cerrado (Brazilian savanna) and semideciduous forest, Southeastern Brazil. Plant Ecology 160:1-16.

Cummings, V. 2014. Hunter-Gatherers in the Post-Glacial World. In The Oxford Handbook of the Archaeology and Anthropology of Hunter-Gatherers, edited by V. Cummings, P. Jordan, and M. Zvelebil, pp. 437-455. Oxford University Press, Oxford.

Dalton, G. 1977. Aboriginal economies in stateless societies. In Exchange Systems in Prehistory, edited by T.K. Earle and J.E. Ericson, pp. 191-212. Academic Press, San Diego.

Delage, C. 2018. Revisiting Rolling stones: The procurement of non-local goods in the Epipaleolithic of the Near East. Quaternary International 464:159-172.

Dillehay, T.D. and L. Núñez 1988. Camelids, caravans, and complex societies in the south-central Andes. In Recent Studies in Pre-Columbian Archaeology, edited by N. Saunders and V. De Montmollin, pp. 603-663. British Archaeological Reports, Oxford.

Dillehay, T.D. 1999. The late Pleistocene cultures of South America. Evolutionary Anthropology 7:206-216.

Dillehay, T.D. 2013. Economic mobility, exchange, and order in the Andes. In Merchants, Markets, and Exchange in the preColumbian World, edited by K.G. Hirth and J. Pillsbury, pp. 283308. Dumbarton Oaks, Washington, D.C.

Dillian, C.D. and C.L. White 2010. Introduction: Perspectives on trade and exchange. In Trade and Exchange: Archaeological Studies from History and Prehistory, edited by C.D. Dillian and C.L. White, pp. 3-14. Springer, New York.

Farquhar, G. and R. Richards 1984. Isotopic composition of plant carbon correlates with water-use efficiency of wheat genotypes. Australian Journal of Plant Physiology 11:539-552.

Gajardo, R. 1994. La Vegetación Natural de Chile. Editorial Universitaria, Santiago.

Gamble, C. 1982. Interaction and alliance in Palaeolithic society. Man New Series 17:92-107.

Gamble, C. 1999. The Palaeolithic Societies of Europe. Cambridge University Press, Cambridge.

Gayo, E.M., C. Latorre, C.M. Santoro, A. Maldonado, and R. De Pol-Holz 2012. Hydroclimate variability on centennial timescales in the low-elevation Atacama Desert over the last 2,500 years. Climate of the Past 8:287-306.

Gayo, E.M., C. Latorre, and C.M. Santoro 2015. Timing of occupation and regional settlement patterns revealed by time-series analyses of an archaeological radiocarbon database for the SouthCentral Andes (16 ${ }^{\circ}-25^{\circ}$ S). Quaternary International 356:4-14.

Gould, R.A. and S. Saggers 1985. Lithic procurement in central Australia: A closer look at Binford's idea of embeddedness in archaeology. American Antiquity 50:117-136.

Grosjean, M., L. Núñez, and I. Cartajena 2005. Palaeoindian occupation of the Atacama Desert, northern Chile. Journal of Quaternary Science 20:643-653.

Grove, M. 2014. Hunter-gatherer settlement and mobility. In Encyclopedia of Global Archaeology, edited by C. Smith, pp. 3567-3577. Springer, New York.

Gusinde, M. 1991 [1974]. Los Indios de Tierra del Fuego. Volume III (I). Los Halakwulup. Centro Argentino de Etnología Americana, Buenos Aires.
Guzmán, N., S. Saá, and L. Ortlieb 1998. Catálogo descriptivo de los moluscos litorales (gastropoda y pelecypoda) de la zona de Antofagasta, $23^{\circ} \mathrm{S}$ (Chile). Estudios Oceanológicos 17:17-86.

Hamilton, M.J., B.T. Milne, R.S. Walker, O. Burger, and J.H. Brown 2007. The complex structure of hunter-gatherer social networks. Proceedings of the Royal Society of London B: Biological Sciences 274:2195-2203.

Häussermann, V. and G. Försterra 2009. Marine Benthic Fauna of Chilean Patagonia. Nature in Focus, Santiago.

Herrera, K. 2017. Peuplement Humain à la Transition Pléistocène Holocène au Désert d'Atacama: Contribution à l'Étude de la Technologie Lithique du site Chipana-1, Chili. Universite Paris X Nanterre, Paris.

Herrera, K., P.C. Ugalde, D. Osorio, J.M. Capriles, S. Hocsman, and C.M. Santoro 2015. Análisis tecno-tipológico de instrumentos líticos del sitio Arcaico Temprano Ipilla 2 en los Andes de Arica, Chile. Chungara Revista de Antropología Chilena 47 (1):41-52.

Hirth, K.G. and J. Pillsbury 2013. Merchants, markets, and exchange in the pre-Columbian world. In Merchants, Markets, and Exchange in the pre-Columbian World, edited by K.G. Hirth and J. Pillsbury, pp. 1-22. Dumbarton Oaks, Washington, D.C.

Huber, M. 2010. Compendium of Bivalves. ConchBook, Hackenheim.

IAWA-Committee 1989. IAWA List of Microscopic Features for Hardwood Identification. IAWA Bulletin 10:219-332.

Hodder, I. 1982 Trade and exchange: Definitions, identification and function. In Models and Methods in Regional Exchange, edited by R. Fry, pp. 151-156. SAA Papers 1, Washington, D.C.

Jackson, D., C. Méndez, and E. Aspillaga 2012. Human remains directly dated to the Pleistocene-Holocene transition support a maritime diet among the first settlers of the Pacific coast of South America. Journal of Island and Coastal Archaeology 7:363-377.

Jerez, G. and M. Figueroa 2008. Desafíos y perspectivas de la repoblación de moluscos bivalvos en Chile. In Estado Actual del Cultivo y Manejo de Moluscos Bivalvos y su Proyección Futura: Factores que Afectan su Sustentabilidad en América Latina, edited by A. Lovatelli, A.A. Farías and I. Uriarte, pp. 223-235. FAO Actas de Pesca y Acuicultura. No. 12, Roma.

Joly, D., C.M. Santoro, E.M. Gayo, P.C. Ugalde, R.J. March, R. Carmona, D. Marguerie, and C. Latorre 2017. Fuel management and human colonization of the Atacama Desert, northern Chile, during the Pleistocene-Holocene transition. Latin American Antiquity 28:144-160.

Jordan, P. 2014. The ethnohistory and anthropology of 'modern' hunter-gatherers. In The Oxford Handbook of the Archaeology and Anthropology of Hunter-Gatherers, edited by V. Cummings, P. Jordan, and M. Zvelebil, pp. 903-917. Oxford University Press, Oxford.

Kelly, R.L. 1995. The Foraging Spectrum: Diversity in HunterGatherer Lifeways. Smithsonian Institution Press, Washington D.C.

Kelly, R.L. 2003. Colonization of new land by hunters-gatherers: expectations and implications based on ethnographic data. In Colonization of Unfamiliar Landscapes. The Archaeology of Adaptation, edited by M. Rockman and J. Steele, pp. 44-59. Routledge, London and New York.

Killeen, T.J., A. Jardim, F. Mamani, and N. Rojas 1998. Diversity, composition and structure of a tropical semideciduous forest in the Chiquitanía region of Santa Cruz, Bolivia. Journal of Tropical Ecology 14:803-827. 
C. M. Santoro, E. M. Gayo, J. M. Capriles, M. M. Rivadeneira, K. A. Herrera, V. Mandakovic, M. Rallo, J. A. Rech, B.

Cases, L. Briones, L. Olguín, D. Valenzuela, L. A. Borrero, P. C. Ugalde, F. Rothhammer, C. Latorre, and P. Szpak

Laguens, A.G., M. Giesso, M.I. Bonnin, and M.D. Glascock 2007 Más allá del horizonte: cazadores-recolectores e intercambio a larga distancia en Intihuasi (provincia de San Luis, Argentina) Intersecciones en Antropología 8:7-16.

Lathrap, D.W. 1970. The Upper Amazon. Thames \& Hudson, Southampton.

Latorre, C., J.L. Betancourt, and M.T.K. Arroyo 2006. Late Quaternary vegetation and climate history of a perennial river canyon in the Río Salado basin $\left(22^{\circ} \mathrm{S}\right)$ of northern Chile. Quaternary Research 65:405-466.

Latorre, C., R. de Pol-Holz, C. Carter and C.M. Santoro 2017 Using archaeological shell middens as a proxy for past local coastal upwelling in northern Chile. Quaternary International 427 128-136.

Latorre, C., C.M. Santoro, P.C. Ugalde, E.M. Gayó, D. Osorio, C. Salas-Egaña, R. De Pol-Holz, D. Joly, and J.A. Rech 2013. Late Pleistocene human occupation of the hyperarid core in the Atacama Desert, northern Chile. Quaternary Science Reviews 77:19-30.

Laudien, J., M.E. Rojo, M.E. Oliva, W.E. Arntz, and S. Thatje 2007. Sublittoral soft bottom communities and diversity of Mejillones Bay in northern Chile (Humboldt Current upwelling system) Helgoland Marine Research 61:103-116.

Lovis, W.A., R.E. Donahue, and M.B. Holman 2005. Long-distance logistic mobility as an organizing principle among northern huntergatherers: A Great Lakes Middle Holocene settlement system. American Antiquity 70:669-693.

Loyola, R., L. Núñez, C. Aschero, and I. Cartajena 2017. Tecnología lítica del Pleistoceno final y la colonización del Salar de Punta Negra (24,5 S), Desierto de Atacama. Estudios Atacameños. Arqueología y Antropología Surandinas 55:5-34.

Luebert, F. and P. Pliscoff 2006. Sinopsis Bioclimática y Vegetacional de Chile. Editorial Universitaria, Santiago.

Lynch, T.F. 1971. Preceramic transhumance in the Callejón de Huaylas, Perú. American Antiquity 36:139-148.

Magnusson, B., T. Näykki, H. v. Hovind, and M. Krysell 2012. Handbook for Calculation of Measurement Uncertainty in Environmental Laboratories, Nordtest Technical Report 537 ed. 3.1 .

Marincovich, L. 1973. Intertidal Mollusks of Iquique, Chile. Los Angeles Natural History Museum, Los Angeles County.

Marquet, P.A., F. Bozinovic, G.A. Bradshaw, C. Cornelius, H González, J.R. Gutiérrez, E.R. Hajek, J.A. Lagos, F. López-Cortés L. Núñez, E.F. Rosello, C.M. Santoro, H. Samaniego, V.G. Standen, J.C. Torres-Mura, and F.M. Jaksic 1998. Los ecosistemas de Desierto de Atacama y área andina adyacente en el norte de Chile. Revista Chilena de Historia Natural 71:593-617.

McBryde, I. 1984. Exchange in south eastern Australia: an ethnohistorical perspective. Aboriginal History 8:132-153.

Méndez, C., O. Reyes, A. Nuevo Delaunay, and E. Latorre 2017. Chenques en el centro oeste de Patagonia (Holoceno Tardío Final, valle de Nirehuao, $45^{\circ} \mathrm{S}$, Chile). Chungara Revista de Antropología Chilena 49 (3):379-395.

Mulvaney, J. 2002. '... these Aboriginal lines of travel'. Historic Environment 16:4-7.

Nester, P.L., E. Gayo, C. Latorre, T.E. Jordan, and N. Blanco 2007. Perennial stream discharge in the hyperarid Atacama Desert of northern Chile during the latest Pleistocene. Proceedings of the National Academy of Sciences 104:19724-19729.
Newlander, K.S. 2012. Exchange, Embedded Procurement, and Hunter-Gatherer Mobility: A Case Study from the North American Great Basin. Doctoral dissertation anthropology, The University of Michigan, Michigan.

Niemeyer, H. and V. Schiappacasse 1979. Investigación de un sito temprano de cazadores-recolectores arcaicos en la desembocadura del valle de Camarones (I región, Chile). Actas del VII Congreso Nacional de Arqueología Chilena, pp. 115-118. Kultrún Ltda., Santiago.

Núñez, L., M. Grosjean, and I. Cartajena 2002. Human occupations and climate change in the Puna de Atacama, Chile. Science 298:821-824

Núñez, L., D. Jackson, T.D. Dillehay, C.M. Santoro, and C. Méndez 2016. Cazadores-recolectores tempranos y los primeros poblamientos en Chile hacia finales del Pleistoceno (ca.13.00010.000 años antes del presente). In Prehistoria en Chile desde sus Primeros Habitantes hasta los Incas, edited by F. Falabella M. Uribe, L. Sanhueza, C. Aldunate, and J. Hidalgo, pp. 71-116. Editorial Universitaria y Sociedad Chilena de Arqueología, Santiago.

Núñez, L., R. Loyola, I. Cartajena, P. López, B. Santander, A. Maldonado, P. de Souza, and C. Carrasco 2018. Miscanti-1: Human occupation during the arid Mid-Holocene event in the high-altitude lakes of the Atacama Desert, South America. Quaternary Science Reviews 181:109-122.

Núñez, L. and A. Nielsen (eds.) 2011. En Ruta: Arqueología Historia y Etnografía del Tráfico Surandino. Encuentro Grupo Editor, Buenos Aires.

Olguín, L. 2013. Aprovechamiento de Invertebrados marinos en conchales arqueológicos del Arcaico Medio (6.000-4.000 a.C.) en la costa de Taltal: estudios preliminares. Revista Taltalia 6:37-53.

Ortlieb, L., J.L. Goy, C. Zazo, C.I. Hillaire-Marcel, and G. Vargas 1995. Late Quaternary coastal changes in northern Chile. Guidebook for a fieldtrip, 23-25 November 1995. II Annual Meeting of the International Geological Correlation Program $(I G C P)$, Project 367. ORSTOM, Antofagasta.

Osorio, C. 2002. Moluscos Marinos en Chile: Especies de Importancia Económica: Guía para su Identificación. Facultad de Ciencias. Universidad de Chile, Santiago.

Osorio, D., J.M. Capriles, P.C. Ugalde, K.A. Herrera, M. Sepúlveda, E.M. Gayó, C. Latorre, D. Jackson, R. De Pol Holz, and C.M. Santoro 2017. Hunter-gatherer mobility strategies in the high Andes of northern Chile during the late Pleistocene-early Holocene transition (ca. 11,500-9,500 cal B.P.). Journal of Field Archaeology 17:228-240.

Osorio, D., J. Steele, M. Sepúlveda, E.M. Gayo, J.M. Capriles, K. Herrera, P.C. Ugalde, R. De Pol-Holz, C. Latorre, and C.M. Santoro 2017. The Dry Puna as an ecological megapatch and the peopling of South America: Technology, mobility, and the development of a late Pleistocene/early Holocene Andean hunter-gatherer tradition in northern Chile. Quaternary International 461:41-53.

Pallo, M. and L.A. Borrero 2015. ¿Intercambio o movilidad?: una evaluación sobre el uso de escalas de análisis espaciales y curvas de decaimiento en Patagonia centro-meridional (Argentina). Latin American Antiquity 23:287-303.

Paskoff, R., E.M. Leonard, J.E. Novoa, L. Ortlieb, U. Radtke, and J. Wehmiller 1995. Field meeting in the La Serena-Coquimbo Bay area (Chile). Guidebook for a fieldtrip, 27-28 November 1995. II Annual Meeting of the International Geological Correlation Program (IGCP), Project 367. ORSTOM, Antofagasta. 
Pearce, E. 2014. Modelling mechanisms of social network maintenance in hunter-gatherers. Journal of Archaeological Science 50:403-413.

Pfeiffer, M., C. Latorre, C.M. Santoro, E.M. Gayo, R. Rojas, M.L. Carrevedo, V.B. McRostie, K.M. Finstad, A. Heimsath, M.C. Jungers, R. De Pol-Holz, and R. Amundson 2018. Chronology, stratigraphy and hydrological modelling of extensive wetlands and paleolakes in the hyperarid core of the Atacama Desert during the late quaternary. Quaternary Science Reviews 197:224-245.

Politis, G.G. 1996. Moving to produce: Nukak mobility and settlement patterns in Amazonia. World Archaeology 27:492-511.

Qi, H., T.B. Coplen, H. Geilmann, W.A. Brand, and J.K. Böhlke 2003. Two new organic reference materials for $\delta^{13} \mathrm{C}$ and $\delta^{15} \mathrm{~N}$ measurements and a new value for the $\delta^{13} \mathrm{C}$ of NBS 22 oil, Rapid Communications in Mass Spectrometry 17 (22): 2483-2487.

Qi, H., T.B. Coplen, S.J. Mroczkowski, W.A. Brand, L. Brandes, H. Geilmann, and A. Schimmelmann 2016. A new organic reference material, l-glutamic acid, USGS41a, for $\delta^{13} \mathrm{C}$ and $\delta^{15} \mathrm{~N}$ measurements - a replacement for USGS41. Rapid Communications in Mass Spectrometry 30 (7): 859-866.

Rademaker, K., M.D. Glascock, B. Kaiser, D. Gibson, D.R. Lux, and M.G. Yates 2013. Multi-technique geochemical characterization of the Alca obsidian source. Peruvian Andes. Geology 41:779-782.

Reid, D.G. and C. Osorio 2000. The shallow-water marine mollusca of the Estero Elefantes and Laguna San Rafael, southern Chile. Bulletin-Natural History Museum Zoology Series 66:109-146.

Reitz, E.J., H.E. McInnis, D.H. Sandweiss, and S.D. deFrance 2016. Terminal Pleistocene and Early Holocene fishing strategies at Quebrada Jaguay and the Ring Site, southern Perú. Journal of Archaeological Science: Reports 8:447-453.

Richter, H.G. and M.J. Dallwitz 2000 onwards. Commercial timbers: descriptions, illustrations, identification, and information retrieval. In English, French, German, Portuguese, and Spanish. Version: 25th June 2009. http://delta-intkey.com.

Rivadeneira, M.M. and E.R. Carmona 2008. A Late Pleistocene macrobenthic assemblage in Caleta Patillos, northern Chile: paleoecological and paleobiogeographical interpretations. Revista Geológica de Chile 35:163-173.

Rockman, M. 2003. Knowledge and learning in the archaeology of colonization. In Colonization of Unifamiliar Landscapes. The Archaeology of Adaptation, edited by M. Rockman and J. Steele, pp. 3-24. Routledge, London and New York.

Rothhammer F., L. Fehren-Schmitz, G. Puddu, and J. Capriles 2017. Mitochondrial DNA haplogroup variation of contemporary mixed South Americans reveals prehistoric displacements linked to archaeologically-derived culture history. American Journal of Human Biology 29:e23029.

Sáez, A., L.V. Godfrey, C. Herrera, G. Chong, and J.J. Pueyo 2016. Timing of wet episodes in Atacama Desert over the last $15 \mathrm{ka}$. The groundwater discharge deposits (GWD) from Domeyko Range at $25^{\circ}$ S. Quaternary Science Reviews 145:82-93.

Salazar, D., D. Jackson, G.L. Guendon, H. Salinas, D. Morata, V. Figueroa, G. Manríquez, and V. Castro 2011. Early evidence (ca. 12,000 BP) for iron oxide mining on the Pacific coast of South America. Current Anthropology 52:463-475.

Salomon, F. 1985. The dynamic potential of the complementarity concept. In Andean Ecology and Civilization. An interdisciplinary perspective on Andean ecological complementarity, edited by S. Masuda, I. Shimada, and C. Morris, pp. 511-531. University of Tokyo Press, Tokyo.
Santoro, C.M., E.M. Gayo, J.M. Capriles, M.E. de Porras, A. Maldonado, V.G. Standen, C. Latorre, V. Castro, D. Angelo, V. McRostie, M. Uribe, D. Valenzuela, P.C. Ugalde, and P.A. Marquet 2017. Continuities and discontinuities in the socio-environmental systems of the Atacama Desert during the last 13,000 years. Journal of Anthropological Archaeology 46:28-39.

Santoro, C.M. and L. Núñez 1987. Hunters of the Dry Puna and Salt Puna in northern Chile. Andean Past 1:57-110.

Seelenfreund, A., M. Pino, M.D. Glascock, C. Sinclaire, P. Miranda, D. Pasten, S. Cancino, M.I. Dinator, and J.R. Morales 2010. Morphological and geochemical analysis of the Laguna Blanca/ Zapaleri obsidian source in the Atacama Puna. Geoarchaeology: An International Journal 25:245-263.

Silveira, M., L. López, and G. Pastorino 2010. Movilidad, redes de intercambio y circulación de bienes en el sudoeste del Neuquén (Norpatagonia, Argentina): los moluscos marinos del lago Traful. Intersecciones en Antropología 11:227-236.

Speth, J.D., K. Newlander, A.A. White, A.K. Lemke, and L.E. Anderson 2013. Early Paleoindian big-game hunting in North America: Provisioning or politics? Quaternary International 285:111-139.

Standen, V.G. and L. Núñez 1984. Indicadores antropológicofísico y culturales del cementerio precerámico Tiliviche-2 (norte de Chile). Chungara Revista de Antropología Chilena 12:135-154.

Standen, V.G., C.M. Santoro, B.T. Arriaza, and D. Coleman 2018. Atacama Desert, strontium isotope, mobility, hunter-gatherers and fishermen, Chinchorro population. Geoarchaeology: An International Journal 33:162-176.

Stewart, G.R., M.H. Turnbull, S. Schmidt, and P.D. Erskine 1995. $13 \mathrm{C}$ natural abundance in plant communities along a rainfall gradient: a biological integrator of water availability. Australian Journal of Plant Physiology 22:51-55.

Still, C.J., J.A. Berry, G.J. Collatz, and R.S. DeFries 2003. Global distribution of $\mathrm{C} 3$ and $\mathrm{C} 4$ vegetation: carbon cycle implications. Global Biogeochemical Cycles 17:6-1-6-14.

Szpak, P. 2013. Stable Isotope Ecology and Human-Animal Interactions in Northern Peru. Department of Anthropology. Western University, London, Ontario.

Szpak, P., J. Z. Metcalfe, and R.A. Macdonald 2017. Best Practices for Calibrating and reporting stable isotope neasurements in archaeology, Journal of Archaeological Science: Reports 13: 609-616.

Szpak, P., J-F. Millaire, C.D. White, and F.J. Longstaffe 2014. Small scale camelid husbandry on the north coast of Peru (Virú Valley): Insight from stable isotope analysis. Journal of Anthropological Archaeology 36:110-129.

Tolan-Smith, C. 2003. The social context of landscape learnig and the lateglacial-early postglaical recolonization of the British Isles. In Colonization of Unfamiliar Landscapes. The Archaeology of Adaptation, edited by M. Rockman and J. Steele, pp. 116-129. Routledge, London and New York.

Tortorelli, L. 1956. Maderas y Bosques Argentinos. ACME, Buenos Aires.

Tripcevich, N. 2010. Exotic goods, Chivay obsidian, and sociopolitical change in the south-central Andes. In Trade and Exchange: Archaeological Studies from History and Prehistory, edited by C.D. Dillian and C.L. White, pp. 59-73. Springer Press, New York.

Ugalde, P.C., C.M. Santoro, E.M. Gayo, C. Latorre, S. Maldonado, R.d. Pol-Holz and D. Jackson 2015. How do surficial lithic assemblages weather in arid environments? A case study from the Atacama Desert of northern Chile. Geoarchaeology: An International Journal 30:352-368. 
Vásquez, J., D. Véliz, and R. Weisner 1998. Analisis malacologico de un yacimiento de la cultura Huentelauquen IV región, Chile. Gayana Oceanológica 42:109-116.

Vermeij, G.J. 2012. The evolution of gigantism on temperate seashores. Biological Journal of the Linnean Society 106:776-793.

Veth, P. 2008. Cycles of aridity and human mobility: Risk minimization among Late Pleistocene foragers of the Western Desert, Australia. In Desert Peoples. Archaeological Perspectives, edited by P. Verth, M. Smith and P. Hiscock, pp. 100-115. Blackwell Publishing Ltd.

Villagrán, C., V. Castro, G. Sánchez, F. Hinojosa, and C. Latorre 1999. La tradición altiplánica: estudio etnobotánico en los Andes de Iquique, primera región, Chile. Chungara Revista de Antropología Chilena 31 (1):81-186.

Villagrán, C., M. Romo, and V. Castro 2003. Etnobotánica del sur de los Andes de la primera región de Chile: un enlace entre las culturas altiplánicas y las de quebradas altas del Loa superior Chungara Revista de Antropología Chilena 35 (2):73-124.
Walker, R.S., K.R. Hill, M.V. Flinn, and R.M. Ellsworth 2011. Evolutionary history of hunter-gatherer marriage practices. PloS One 6(4):e19066.

Whallon, R. 2006. Social networks and information: Non"utilitarian" mobility among hunter-gatherers. Journal of Anthropological Archaeology 25:259-270.

Wiessner, P. 2002. Hunting, healing, and hxaro exchange: A long-term perspective on! Kung (Ju/'hoansi) largegame hunting. Evolution and Human Behavior 23:407436.

Wilkins, J., L. Pollarolo, and K. Kuman 2010. Prepared core reduction at the site of Kudu Koppie in northern South Africa: temporal patterns across the Earlier and Middle Stone Age boundary. Journal of Archaeological Science 37:1-14.

Yacobaccio, H.D., P.S. Escola, F.X. Pereyra, M. Lazzari, and M.D Glascock 2004. Quest for ancient routes: obsidian sourcing research in Northwestern Argentina. Journal of Archaeological Science 31:193-204.

\section{Supplementary Material 1: Methods - Stable Isotope Analysis}

\section{Stable Isotope Analysis - Sample Preparation}

Samples were cleaned of any visible foreign matter with tweezers and then sonicated in Type I water for $1 \mathrm{~h}$, then in 2:1 chloroform:methanol for 1 h. After removing the solvent the samples were air dried under normal atmosphere for at least $24 \mathrm{~h}$.

\section{Stable Isotope Analysis - Instrumentation and Analytical Uncertainty}

Carbon and nitrogen isotopic and elemental compositions were determined using a $\mathrm{Nu}$ Horizon continuous flow isotope ratio mass spectrometer. Sample measurements were calibrated relative to VPDB $\left(\delta^{13} \mathrm{C}\right)$ and AIR $\left(\delta^{15} \mathrm{~N}\right)$ using USGS40 and USGS41a (Table S1; Qi et al., 2003; Qi et al., 2016).

Table S1. Standard reference materials used for calibration of $\delta 13 \mathrm{C}$ relative to VPDB and $\delta 15 \mathrm{~N}$ relative to AIR.

\begin{tabular}{cccc}
\hline Standard & Material & $\begin{array}{c}\text { Accepted } \delta^{13} \mathrm{C} \\
(\% \circ, \text { VPDB })\end{array}$ & $\begin{array}{c}\text { Accepted } \delta^{15} \mathrm{~N} \\
(\% \circ, \text { AIR })\end{array}$ \\
\hline USGS40 & Glutamic Acid & $-26.39 \pm 0.04$ & $-4.52 \pm 0.06$ \\
\hline USGS41a & Glutamic Acid & $+36.55 \pm 0.08$ & $+47.55 \pm 0.15$ \\
\hline
\end{tabular}

The following standards were used to monitor accuracy and precision (Table S2). The isotopic compositions for the internal keratin standard represent long-term averages.
Table S2. Standard reference materials used to monitor internal accuracy and precision.

\begin{tabular}{cccc}
\hline Standard & Material & $\begin{array}{c}\text { Mean } \delta^{13} \mathrm{C} \\
(\% \%, \mathrm{VPDB})\end{array}$ & $\begin{array}{c}\text { Mean } \delta^{15} \mathrm{~N} \\
(\% \%, \mathrm{AIR})\end{array}$ \\
\hline SRM-1 & Caribou bone collagen & $-19.36 \pm 0.11$ & $+1.81 \pm 0.10$ \\
\hline SRM-2 & Walrus bone collagen & $-14.76 \pm 0.12$ & $+15.59 \pm 0.11$ \\
\hline SRM-4 & Gluten & $-26.76 \pm 0.08$ & $+5.25 \pm 0.11$ \\
\hline SRM-14 & Polar bear bone collagen & $-13.66 \pm 0.07$ & $+21.62 \pm 0.12$ \\
\hline
\end{tabular}

Table S3 summarizes the mean and standard deviation of carbon and nitrogen isotopic compositions for all check standards, as well as the standard deviation for all calibration standards - the mean of the calibration standard for an individual run is predetermined to calibrate the data.

Table S3. Mean and standard deviation of all check and calibration standards for all analytical sessions containing data presented in this paper. Note that means for calibration standards are not presented as they are pre-determined to be equal to the known value.

\begin{tabular}{cccrrrrrr}
\hline $\begin{array}{c}\text { Run } \\
\text { ID }\end{array}$ & Standard & $\mathrm{n}$ & \multicolumn{2}{c}{$\boldsymbol{\delta}^{13} \mathrm{C}(\%, \mathrm{VPDB})$} & \multicolumn{2}{c}{$\boldsymbol{\delta}^{15} \mathrm{~N}(\% \circ, \mathrm{AIR})$} \\
\hline $18-03$ & USGS40 & 5 & & \pm & 0.13 & & \pm & 0.06 \\
\hline $18-04$ & USGS40 & 5 & & \pm & 0.04 & & \pm & 0.05 \\
\hline $18-03$ & USGS41a & 5 & & \pm & 0.14 & & \pm & 0.06 \\
\hline $18-04$ & USGS41a & 5 & & \pm & 0.12 & & \pm & 0.06 \\
\hline $18-03$ & SRM-4 & 5 & -26.72 & \pm & 0.12 & +5.28 & \pm & 0.04 \\
\hline $18-03$ & SRM-2 & 4 & -14.84 & \pm & 0.08 & +15.62 & \pm & 0.07 \\
\hline $18-03$ & SRM-14 & 4 & -13.70 & \pm & 0.09 & +21.59 & \pm & 0.11 \\
\hline $18-04$ & SRM-1 & 4 & -19.34 & \pm & 0.07 & +1.82 & \pm & 0.07 \\
\hline $18-04$ & SRM-2 & 4 & -14.77 & \pm & 0.03 & +15.58 & \pm & 0.09 \\
\hline $18-04$ & SRM-14 & 4 & -13.61 & \pm & 0.03 & +21.59 & \pm & 0.03 \\
\hline
\end{tabular}

One sample (\#529) was analyzed in duplicate. The difference between the duplicate measurements was $0.15 \%$ for $\delta^{13} \mathrm{C}$ and $0.14 \%$ for $\delta^{15} \mathrm{~N}$. 


\section{Analytical Uncertainty}

Standard uncertainty was calculated using the method present by Szpak et al. (2017), which largely follows Magnusson et al.'s (2012) approach. Standard uncertainty was determined to be $\pm 0.16 \%$ o for $\delta^{13} \mathrm{C}$ and $\pm 0.15 \%$ o for $\delta^{15} \mathrm{~N}$.

\section{Results}

The carbon and nitrogen isotopic and elemental compositions of all samples analyzed are presented in Table S4.

Table S4. Stable isotopic and elemental compositions for all samples analyzed in this study.

\begin{tabular}{|c|c|c|c|c|c|c|c|}
\hline Lab ID & Sample ID & Taxon & $\delta^{13} \mathrm{C}(\% \circ)$ & $\delta^{15} \mathrm{~N}(\% o)$ & $\mathrm{wt} \% \mathrm{C}$ & $\mathrm{wt} \% \mathrm{~N}$ & Atomic $\mathrm{C}: \mathrm{N}$ \\
\hline 518 & QM32_S1E8_C2b/R2_M518 & Monochrome yarn 2ZS & -19.74 & 5.64 & 26.6 & 8.4 & 3.69 \\
\hline 519 & QM32_S1E8_C2b/R2_M519 & Monochrome yarn 2ZS & -18.89 & 9.38 & 15.4 & 4.9 & 3.67 \\
\hline 520 & QM32_S2E8_C2c_M520 & Fleece, vicuña? & -17.08 & 7.61 & 30.5 & 9.4 & 3.78 \\
\hline 521 & QM32_S2E8_C1_M521 & Fleece, with red pigment? & -18.94 & 7.38 & 31.8 & 9.6 & 3.86 \\
\hline 522 & QM32_S2E9_C1_M522 & Yellowish beige fleece & -19.27 & 6.45 & 34.2 & 10.1 & 3.95 \\
\hline 523 & QM32_S2E9_C2_M523 & Cotton & -24.06 & -3.06 & 29.6 & 0.5 & 69.04 \\
\hline 524 & QM32_S1E8_C2B_M524 & Z- twisted monochrome fleece & -21.32 & 4.65 & 34.2 & 11.7 & 3.66 \\
\hline 525 & QM32_S1E9_C2ab_M525 & Fleece with cut marks & -18.99 & 8.96 & 34.7 & 11.0 & 3.68 \\
\hline 526 & QM32_S2E8_C2DE_M526 & $\begin{array}{c}\text { S-twisted monochrome fleece, } \\
\text { vizcacha? }\end{array}$ & -20.44 & 4.54 & 36.7 & 11.0 & 3.89 \\
\hline 527 & QM32_S2E8_C2DE_M527 & Vizcacha fleece-hair? & -21.51 & 6.65 & 24.3 & 7.2 & 3.94 \\
\hline 528 & QM32_S2E8_C2AB_M528 & Felted fleece & -21.25 & 3.67 & 35.8 & 10.6 & 3.94 \\
\hline 529 & QM32_S2E8_C2AB_M529 & Guanaco? fleece & -20.48 & 4.01 & 37.2 & 11.3 & 3.84 \\
\hline
\end{tabular}


